San Jose State University

SJSU ScholarWorks

Mineta Transportation Institute Publications

$11-2021$

\title{
How Do California's Local Governments Fund Surface Transportation? A Guide to Revenue Sources
}

Asha Weinstein Agrawal

San Jose State University, asha.weinstein.agrawal@sjsu.edu

Kevin Yong Lee

San Jose State University

Serena Alexander

San Jose State University, serena.alexander@sjsu.edu

Follow this and additional works at: https://scholarworks.sjsu.edu/mti_publications

Part of the Infrastructure Commons, and the Transportation Commons

\section{Recommended Citation}

Asha Weinstein Agrawal, Kevin Yong Lee, and Serena Alexander. "How Do California's Local Governments Fund Surface Transportation? A Guide to Revenue Sources" Mineta Transportation Institute Publications (2021). https://doi.org/10.31979/mti.2021.1938A

This Report is brought to you for free and open access by SJSU ScholarWorks. It has been accepted for inclusion in Mineta Transportation Institute Publications by an authorized administrator of SJSU ScholarWorks. For more information, please contact scholarworks@sjsu.edu. 


\section{SJSU UNIVESSITY

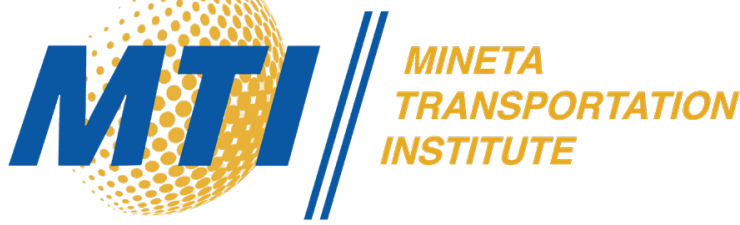

How Do California's Local Governments Fund Surface Transportation? A Guide to Revenue Sources

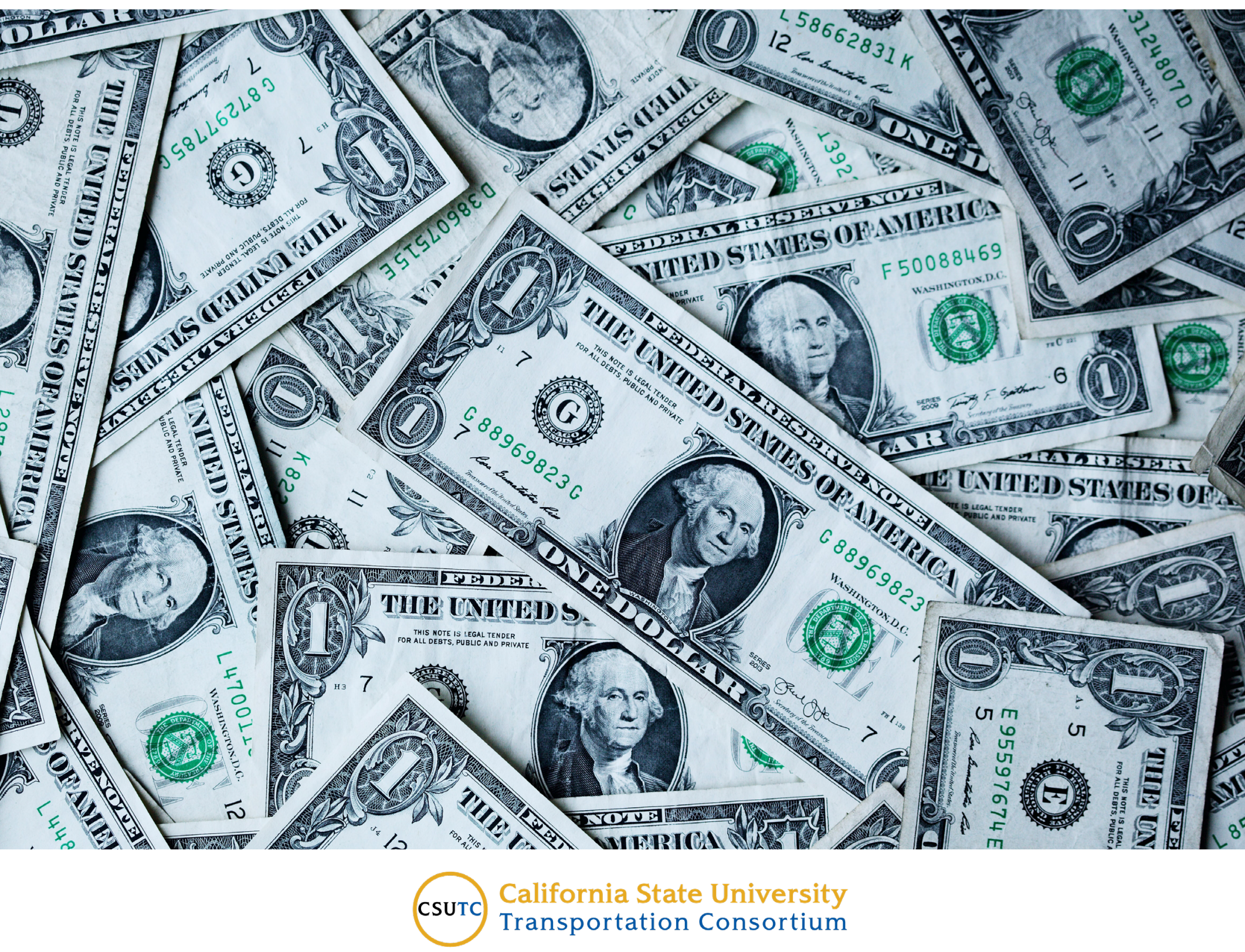




\section{MINETA TRANSPORTATION INSTITUTE}

Founded in 1991, the Mineta Transportation Institute (MTI), an organized research and training unit in partnership with the Lucas College and Graduate School of Business at San José State University (SJSU), increases mobility for all by improving the safety, efficiency, accessibility, and convenience of our nation's transportation system. Through research, education, workforce development, and technology transfer, we help create a connected world. MTI leads the Mineta Consortium for Transportation Mobility (MCTM) funded by the U.S. Department of Transportation and the California State University Transportation Consortium (CSUTC) funded by the State of California through Senate Bill I.MTI focuses on three primary responsibilities:

\section{Research}

MTI conducts multi-disciplinary research focused on surface transportation that contributes to effective decision making. Research areas include:active transportation; planning and policy; security and counterterrorism; sustainable transportation and land use; transit and passenger rail; transportation engineering; transportation finance; transportation technology; and workforce and labor. MTI research publications undergo expert peer review to ensure the quality of the research.

\section{Education and Workforce Development}

To ensure the efficient movement of people and products, we must prepare a new cohort of transportation professionals who are ready to lead a more diverse, inclusive, and equitable transportation industry. To help achieve this, MTI sponsors a suite of workforce development and education opportunities. The Institute supports educational programs offered by the Lucas Graduate School of Business: a Master of Science in Transportation Management, plus graduate certificates that include High-Speed and Intercity Rail Management and Transportation Security Management. These flexible programs offer live online classes so that working transportation professionals can pursue an advanced degree regardless of their location.

\section{Information and Technology Transfer}

MTI utilizes a diverse array of dissemination methods and media to ensure research results reach those responsible for managing change. These methods include publication, seminars, workshops, websites, social media, webinars, and other technology transfer mechanisms. Additionally, MTI promotes the availability of completed research to professional organizations and works to integrate the research findings into the graduate education program. MTI's extensive collection of transportation-related publications is integrated into San José State University's world-class Martin Luther King, Jr. Library.

\section{Disclaimer}

The contents of this report reflect the views of the authors, who are responsible for the facts and accuracy of the information presented herein. This document is disseminated in the interest of information exchange. MTl's research is funded, partially or entirely, by grants from the U.S. Department of Transportation, the U.S. Department of Homeland Security, the California Department of Transportation, and the California State University Office of the Chancellor, whom assume no liability for the contents or use thereof. This report does not constitute a standard specification, design standard, or regulation. 
REPORT 21-32

\title{
HOW DO CALIFORNIA'S LOCAL GOVERNMENTS FUND SURFACE TRANSPORTATION? A GUIDE TO REVENUE SOURCES
}

\author{
Asha Weinstein Agrawal, PhD \\ Kevin Yong Lee \\ Serena Alexander, $\mathrm{PhD}$
}

November 2021

A publication of

Mineta Transportation Institute

Created by Congress in 1991

College of Business

San José State University

San José, CA 95192-0219 


\section{TECHNICAL REPORT DOCUMENTATION PAGE}

1. Report No. 21-32

4. Title and Subtitle

How Do California's Local Governments Fund Surface Transportation? A Guide to Revenue Sources

\section{Authors}

Asha Weinstein Agrawal, PhD

Kevin Yong Lee

Serena Alexander, PhD

9. Performing Organization Name and Address

Mineta Transportation Institute

College of Business

San José State University

San José, CA 95192-0219

12. Sponsoring Agency Name and Address

State of California SB1 2017/2018

Trustees of the California State

University

Sponsored Programs Administration

401 Golden Shore, 5th Floor

Long Beach, CA 90802
2. Government Accession No.

3. Recipient's Catalog No.

5. Report Date

November 2021

6. Performing Organization Code

8. Performing Organization Report

CA-MTI-1938A

10. Work Unit No.

11. Contract or Grant No. ZSB12017-SJAUX

13. Type of Report and Period Covered Final Report

14. Sponsoring Agency Code

15. Supplemental Notes

DOI: 10.31979/mti.2021.1938A

\section{Abstract}

California local agencies raise the revenue to support high-quality transportation services and infrastructure from a patchwork of federal, state, and local sources. To assist policymakers and transportation experts as they explore options for creating a more sustainable funding system, this report presents an overview of the taxes and fees that currently generate revenue ultimately dedicated to paying for transportation at the sub-state-or "local"-level. The discussion covers federal and state as well as local sources. The report also traces the evolving contribution from each level of government for expenditures on California's local streets and roads and public transit, looking back two decades. The report concludes with a discussion of options for increasing local transportation revenue.

\section{Key Words}

Revenues, Types of taxes, Local government, Streets and roads, Public transit

\section{Distribution Statement}

No restrictions. This document is available to the public through The National Technical Information Service, Springfield, VA 22161
19. Security Classif. (of this report) Unclassified
20. Security Classif. (of this page) Unclassified
21. No. of Pages

56
22. Price 


\title{
Copyright $\odot 2021$ \\ by Mineta Transportation Institute \\ All rights reserved
}

DOI: 10.31979/mti.2021.1938A

\author{
Mineta Transportation Institute \\ College of Business \\ San José State University \\ San José, CA 95192-0219 \\ Tel: (408) 924-7560 \\ Fax: (408) 924-7565 \\ Email: mineta-institute@sjsu.edu
}

transweb.sjsu.edu 


\section{ACKNOWLEDGMENTS}

We thank the three anonymous reviewers who provided valuable comments, the many transportation funding experts who answered questions or pointed us to data, Editing Press for editing, Alverina Weinardy for graphic design, the Mineta Transportation Institute for funding the research, and MTI staff for support, including Executive Director Karen Philbrick, PhD, and Communications and Operations Manager Irma Garcia. 


\section{TABLE OF CONTENTS}

1. Introduction 1

2. An Overview of Sources of Surface Transportation Revenue in California 3 2.1. Tools to Raise Revenue: Taxes vs. Fees 3

2.2. Types of Local Government Entities That Impose Taxes and Fees 3

2.3. Taxes and Fees That Generate Earmarked Transportation Revenue 5

2.4. Streets and Roads: Local, State, and Federal Contributions 7

2.5. Public Transit: Local, State, and Federal Contributions 11

3. Federal Revenue Sources 14

3.1. Motor Fuel Excise Tax 14

3.2. Heavy Truck and Trailer Sales Tax 14

3.3. Excise Tax on Heavy-Duty Tire Sales 14

3.4. Heavy Vehicle Use Tax 15

4. State Revenue Sources 16

4.1. Gasoline Motor Fuel Excise Tax 16

4.2. Diesel Motor Fuel Excise Tax 17

4.3. Sales Tax on Diesel Fuel 17

4.4. Transportation Improvement Fee 17

4.5. Road Improvement Fee 17

4.6. Vehicle Weight Fee 18

4.7. Bradley-Burns Uniform Local Sales and Use Tax 18

4.8. Cap and Trade Program 18

5. Local Revenues: Cities, Counties, and Special Districts 19

5.1. Local-Option Sales Tax 19

5.2. County Transportation Project Fee (Vehicle Registration Fee) 20

5.3. Parking Fees 22

5.4. Tolls on Bridges and Roads 22

5.5. Development Impact Mitigation Fees 24

5.7. Transit Fares 25

5.8. Parcel Tax 25

5.9. Transient Occupancy Tax $\quad 26$

5.10. User Utility Tax 27

5.11. Transportation Network Company User Tax 27 
5.12. Business License Tax $\quad 28$

5.13. Enhanced Infrastructure Finance Districts 28

6. Moving Forward: Options for Raising Local Revenue $\quad 30$

6.1. A Summary of Revenue Earmarked for Local Transportation 30

6.2. Looking Forward: Options 30

6.3. Strategies for Identifying the Best Options 33

Appendix A: Details on Revenue Source by Level of Government 35

$\begin{array}{lr}\text { Endnotes } & 37\end{array}$

$\begin{array}{ll}\text { Bibliography } & 48\end{array}$

$\begin{array}{ll}\text { About the Authors } & 56\end{array}$ 


\section{LIST OF FIGURES}

1. Billions of Nominal Dollars Available for Roads and Streets, by Level of Government, 1999-2019

2. Billions of 2020 Dollars Available for Roads and Streets, by Level of Government, 1999-2019

3. Percent of Revenue for Roads and Streets Provided by Each Level of Government, 1999-2019

4. Billions of Nominal Dollars Available for Public Transit, by Level of Government and By Fares, 2003-2017

5. Billions of 2020 Dollars Available for Public Transit, by Level of Government and by Fares, 2003-2017

6. Percent of Revenue for Public Transit in Provided by Each Level of Government and By Fares, 2003-2017 


\section{LIST OF TABLES}

1. Types of Special Districts that Provide Transportation Services or Infrastructure 5

2. Types of Revenue Instruments that Raise Funds Earmarked for Local Transportation

3. California Counties with a CTPF Registration Charge

4. Entities Operating Tolled Facilities in California

A1. Revenue Available for Roads and Streets, by Level of Government, 1999-2019 35

A2. Revenue Available for Public Transit, by Level of Government, 2003-2017 


\section{INTRODUCTION}

California's local governments face a perennial challenge in raising the revenue required to support high-quality transportation services and infrastructure. To assist policymakers and transportation experts as they explore options for creating a more sustainable funding system, this report presents an overview of the taxes and fees that currently generate revenue dedicated to paying for transportation at the sub-state-or "local"-level. We use the term local to refer to counties, cities, and special districts, including entities that have regional responsibility, such as the Bay Area Toll Authority.

Even before the COVID-19 pandemic, funding for both streets and roads and public transit was insufficient to keep the systems in good repair and provide high-quality services. For example, a 2021 assessment from the League of California Cities found that expenditures for local streets and roads would need to be increased by $\$ 64$ billion over the next ten years in order to achieve a state of good repair for all pavement, bridges, and other essential network components (streetlights, storm drains, sidewalks, etc.). ${ }^{1}$ Public transit operators face similar revenue struggles. Ridership across the country has been steadily declining over the years, yet many systems need to upgrade antiquated infrastructure and poorly maintained facilities.

The COVID-19 pandemic brought into sharper focus the long-standing issue of how California's local governments pay for transportation. Most critically, ridership-and therefore fare revenue-fell during the pandemic as much as $90 \%$ for some transit operators. For the industry overall, the American Public Transit Association estimated that ridership was down $66 \%$ for the week of January 3, 2021, as compared to the same week in January $2020 .^{2}$ Further, Americans have modestly reduced vehicle travel and more substantially changed their purchasing behaviors in the face of the pandemic. These changes impact revenue from sources that provide critical transportation funding for local entities, most notably fuel and sales taxes. The extent of those reductions remains to be seen, though a January 2021 update to the state's budget estimated a drop of $8.4 \%$ in gasoline consumption, an increase of $3.7 \%$ in diesel consumption, and a slight increase in sales tax revenue. ${ }^{3}$ The impacts have varied widely across local jurisdictions, however, with some jurisdictions seeing much larger declines in driving, taxable retail sales, and other activities that generate transportation revenue.

This research focuses on the transportation revenue available to the state's local entities. Local governments are responsible for virtually all public transit services and $86 \%$ of roads in the state ${ }^{4}$ yet their unique challenges are often overlooked in state-wide policy discussions and research into transportation revenue options.

One major barrier to an effective state-wide discussion about how California can generate stable funding for local transportation is the fact that the current system is, to speak bluntly, bewildering. Every year, 482 cities, 58 counties, and numerous special districts piece together the puzzle of their transportation budgets, drawing upon a complex mix of revenue raised at every level of government-federal, state, regional, and local. ${ }^{5}$ Indeed, the budget for the transportation program of even a relatively small city, county, or transit operator relies on revenue raised by at least a dozen sources. 
The majority of transportation revenue at the local level comes from a combination of local sales taxes imposed in 25 counties, ${ }^{6}$ plus a host of different taxes and fees paid by direct users of the transportation system, with the proceeds dedicated for transportation purposes by law. Examples of user fees include motor fuel taxes, truck weight fees, public transit fares, parking fees, and local vehicle registration fee surcharges. In addition, government entities also make annual allocations from their general fund revenue to supplement the revenue raised directly from transportation users.

This report is the first of a two-part series that aims to support meaningful dialog about local transportation funding options among policymakers, stakeholders, transportation professionals, and researchers. This first report provides a snapshot of the different revenue tools currently used in the state, as well as some options used outside California. (The report provides basic information about the revenue options, but deliberately does not attempt to analyze their suitability or recommend which have more or less merit.) The second study will report findings from a set of interviews with transportation experts about the challenges they face in raising adequate revenue, and their ideas for innovations and reforms.

This report focuses on those taxes and fees that raise at least some revenue that is dedicated for transportation purposes at the local level, whether the revenue is spent by cities, counties, or special districts. In some cases, the revenue is restricted by law to transportation purposes only, while in other cases the governing body has passed a resolution documenting an ongoing intent to allocate revenue for transportation purposes.

The remainder of the report is organized as follows:

- Chapter 2 provides an overview of the different local, state, and federal revenue sources from which at least some portion is earmarked for local transportation;

- Chapter 3 describes the primary federal revenue sources;

- Chapter 4 describes the primary state revenue sources;

- Chapter 5 describes the primary local revenue sources; and

- Chapter 6 concludes the report with a discussion of options for increasing local transportation revenue. 


\section{AN OVERVIEW OF SOURCES OF SURFACE TRANSPORTATION REVENUE IN CALIFORNIA}

This chapter provides a high-level survey of the revenue tools used to raise local transportation funding. The initial sections describe the conceptual differences between taxes and fees, the different types of local government entities that impose taxes and fees, and an overview of the types of taxes and fees that generate revenue dedicated for surface transportation. The last sections present data on the relative amount of revenue contributed by local governments, the state, and the federal government.

\subsection{TOOLS TO RAISE REVENUE: TAXES VS. FEES}

The State of California's legal code carefully restricts the mechanisms that government entities may use to raise revenue. Many of these laws and constitutional amendments govern activity by both the state itself and local entities. In addition, the state places further limits on the revenue tools available to local governments.

Within California law, the terms "tax" and "fee" refer to different types of charges. "Fees," sometimes known as "enterprise revenues," are charged in exchange for a specific service. The rate should be set so that the governing entity recoups only the revenue needed to provide the service, and the revenue collected must not be used for other purposes. Elected officials may impose fees directly, without voter approval. Examples of fees include charges for obtaining licenses and permits, parking, or driving on a tolled highway.

Local government charges that are not "fees" are usually considered "taxes." The revenue raised from taxes, sometimes called "non-enterprise revenue," typically has fewer restrictions than fees on how the money can be spent. Ad valorem property taxes and parcel taxes are examples of non-enterprise revenues. ${ }^{7}$ A final important concept related to taxes is the distinction between "general" and "special" taxes. "Special taxes" are similar in concept to a fee, in that the revenue collected through a special tax can only be spent for specific purposes. Two-thirds of voters are required to approve a special tax. By contrast, general tax revenue can be spent on any purpose, and these taxes need approval from the majority of voters. ${ }^{8}$

Although these are less commonly used tools to generate transportation revenue in California, local governments can also raise revenue through mechanisms such as fines and penalties, franchise agreements on solid waste collection and utilities, and payments that a private entity pays to use public property (rents, royalties, and concessions). ${ }^{9}$

\subsection{TYPES OF LOCAL GOVERNMENT ENTITIES THAT IMPOSE TAXES AND FEES}

The State of California recognizes three types of local government entities: counties, cities, and special districts.

State land is distributed across 58 counties. Counties provide some services and programs to all residents within their boundaries (e.g., managing federally funded public assistance 
programs and running local elections), as well as providing essential services for residents who do not live within the boundaries of a city or special district that provides such services. Roads are one essential service that counties provide to residents living in unincorporated areas (i.e., areas that are not part of a city). ${ }^{10}$

An "incorporated city" is an area within a county that has been legally designated as the local entity which will provide (and pay for) an array of basic services for its residents. These responsibilities including the provision and management of local streets. Some cities, known as "full service," have financial responsibility for providing the great majority of essential services. However, many cities transfer financial responsibility for certain services to either the county or special districts. ${ }^{11}$

Special districts are forms of local government that provide specific public services within their jurisdiction such as water, sewage, electricity, and fire protection. ${ }^{12}$ The California State Controller reported over 3,000 active special districts in the state for 2018. These vary in size and services, with some exclusively, or in part, providing transportation infrastructure services. ${ }^{13}$ "Independent" special districts have their own governing bodies and are not directly accountable to any other local entity. "Dependent" special districts have a close relationship with another local governing entity, typically a county or city, and that entity's elected leaders control the special district. ${ }^{14}$ Table 1 presents the different types of special districts that have transportation responsibilities.

Two types of special districts that are particularly important from a transportation perspective are congestion management agencies (CMAs) and public transit operators. CMAs are special districts representing a single county that distribute state transportation revenue and may serve as the agency that administers a locally approved transportation sales tax. Some of these, such as the Los Angeles County Metropolitan Transportation Authority, are contiguous with a county, and thus the same elected officials govern both the county and special district. As for public transit districts, these entities' primary mission is operating local or regional public transportation services (e.g., bus or rail). Two examples of independent special districts that operate transit services are the San Francisco Bay Area Rapid Transit (BART) District and the Alameda-Contra Costa Transit Agency (AC Transit). Each entity has its own governing board and legal authority to impose taxes and fees. 


\section{Table 1. Types of Special Districts that Provide Transportation Services or Infrastructure}

\begin{tabular}{ll}
\hline District type & Purpose \\
\hline Transit districts & $\begin{array}{l}\text { Construct and operate rail lines, bus lines, stations, platforms, terminals, and any } \\
\text { other facilities necessary or convenient for transit service }\end{array}$ \\
Community services districts & $\begin{array}{l}\text { Provide up to } 32 \text { different services, including the construction, improvement, and } \\
\text { maintenance of streets, roads, rights-of-way, bridges, and sidewalks. }\end{array}$ \\
Municipal utility districts & $\begin{array}{l}\text { Manage and supply light, water, power, heat, transportation, telephone service, or } \\
\text { other means of communication, or means for the collection, treatment, or disposition } \\
\text { of garbage, sewage or refuse matter }\end{array}$ \\
Public utility districts & $\begin{array}{l}\text { Maintain the infrastructure to provide electricity, natural gas, water, power, heat, } \\
\text { transportation, telephone service, or other means of communication, or the } \\
\text { disposition of garbage, sewage, or refuse matter }\end{array}$ \\
Harbor districts & $\begin{array}{l}\text { Manage any bay, harbor, inlet, river, channel, etc. in which tides are affected by the } \\
\text { Pacific Ocean }\end{array}$ \\
Airport districts & $\begin{array}{l}\text { Assist in the development of airports, spaceports, and air navigation facilities } \\
\text { Port districts }\end{array}$ \\
Recreation and park districts & $\begin{array}{l}\text { Organize and promote programs of community recreation, parks and open space, } \\
\text { parking, transportation, and other related services that improve the community's } \\
\text { quality of life }\end{array}$
\end{tabular}

Source: California Special Districts Association, "Special District Formation Guide" (2016), https://calafco.org/sites/ default/files/documents/2016\%20Formation\%20Guide\%20WEB.PDF.

\subsection{TAXES AND FEES THAT GENERATE EARMARKED TRANSPORTATION REVENUE}

It is surprisingly difficult to identify the set of revenue tools that fund transportation, let alone document the amount of revenue that each raises statewide. The following are some of the key reasons:

- While some special taxes or fees are clearly and completely designated for transportation purposes (e.g., fuel taxes), many other revenue instruments are used for transportation in some but not all jurisdictions. For example, only a few jurisdictions designate that some portion of their parking fee revenue be spent for transportation purposes.

- Sometimes only a portion of the revenue raised from a specific source may be dedicated for transportation (e.g., the state sales tax on diesel fuel).

- Some taxes and fees that one might reasonably assume must be "transportation user fees" with revenue dedicated to the system are actually not sources of transportation funding. Two examples are the state's Vehicle License Fee and parking revenue from most (but not all) local entities.

- Some portion of local, state, and federal "general fund" (unrestricted) revenues also pay for transportation, but the amount is determined each year in the budget allocation process, and there are no centralized, statewide records documenting statewide what portion of local transportation budgets comes from these general fund sources. 
- Least visible of all, but critically important, not all expenditures that directly benefit travel infrastructure and services are labeled as "transportation" expenditures in official reporting. As a result, these remain invisible in any "transportation" accounting even at the level of a single entity. For example, storm-water management infrastructure is typically not documented in accountings of "transportation," even though these systems lie directly along roadways and control roadway flooding. Also, in many locations street-lighting and road-side landscaping are managed by a department of public works rather than a department of transportation, so are not recorded as transportation expenditures. And to give a final example, electric vehicle charging infrastructure has not typically been considered a transportation function in budget reports.

Despite these many complications, there are a set of revenue tools commonly used and documented as raising transportation revenue. Table 2 presents the revenue tools that are the focus of this report-those generating funds that are earmarked for local entities to spend on surface transportation. This set includes federal, state, and local charges. In many cases, the taxes and fees discussed are by statute dedicated for transportation purposes. However, we also describe taxes and fees for which local governing body has formally resolved to spend a portion of the revenue on transportation purposes over many years.

Despite these many complications, there are a set of revenue tools commonly used and documented as raising transportation revenue. Table 2 presents the revenue tools that are the focus of this report-those generating funds that are earmarked for local entities to spend on surface transportation. This set includes federal, state, and local charges. In many cases, the taxes and fees discussed are by statute dedicated for transportation purposes. However, we also describe taxes and fees for which local governing body has formally resolved to spend a portion of the revenue on transportation purposes over many years.

This study excludes from consideration the following types of taxes and fees:

- Taxes and fees that provide "generalfund" revenue, without any accompanying legislative resolution to dedicate the money to transportation: Although some government entities allocate a portion of their unrestricted general fund revenue for transportation, that decision is made annually and there is no guarantee of a continuing revenue stream. Examples of such general-purposes taxes are general property taxes and income taxes.

- Taxes and fees paid by users of the transportation system for which the revenue is never transferred to cities or counties for transportation purposes: Examples include the state driver license and vehicle registration fees (these fund the state's Department of Motor Vehicles and Highway Patrol), the state Vehicle License Fee (a property tax on vehicle ownership), and the parking fees collected in most local jurisdictions.

- Proceeds from bond measures: Bonds are a financing tool that allows 
governments to spend money earlier than they collect it, but bonds do not generate "revenue." As any person with a home loan, auto loan, or credit card knows, borrowed money must eventually be repaid.

Table 2. Types of Revenue Instruments that Raise Funds Earmarked for Local Transportation

\begin{tabular}{|c|c|c|c|c|c|}
\hline Type of revenue instrument, by tax base & Federal & State & $\begin{array}{l}\text { Special } \\
\text { district }\end{array}$ & County & City \\
\hline \multicolumn{6}{|l|}{ Fuels } \\
\hline Gasoline fuel excise tax & $\checkmark$ & $\checkmark$ & & & \\
\hline Diesel fuel excise tax & $\checkmark$ & $\checkmark$ & & & \\
\hline Diesel fuel sales tax & & $\checkmark$ & & & \\
\hline \multicolumn{6}{|l|}{ Vehicles } \\
\hline Truck and truck-tire sales tax & $\checkmark$ & & & & \\
\hline Truck weight fee & $\checkmark$ & $\checkmark$ & & & \\
\hline Vehicle registration fee & & & & $\checkmark$ & \\
\hline \multicolumn{6}{|l|}{ Transportation system use } \\
\hline Toll & & & $\checkmark$ & $\checkmark$ & \\
\hline Fares + other transit-operator-generated revenue ${ }^{a}$ & & & $\checkmark$ & $\checkmark$ & $\checkmark$ \\
\hline Parking fees & & & $\checkmark$ & & $\checkmark$ \\
\hline Ride-hailing tax & & & & & $\checkmark$ \\
\hline Refuse vehicle impact fee & & & $\checkmark$ & $\checkmark$ & $\checkmark$ \\
\hline \multicolumn{6}{|l|}{ Real property } \\
\hline Development fee & & & $\checkmark$ & $\checkmark$ & $\checkmark$ \\
\hline User-utility tax & & & $\checkmark$ & $\checkmark$ & $\checkmark$ \\
\hline Occupancy tax & & & & $\checkmark$ & $\checkmark$ \\
\hline Parcel tax & & & $\checkmark$ & $\checkmark$ & $\checkmark$ \\
\hline \multicolumn{6}{|l|}{ Other } \\
\hline Sales tax & & $\checkmark$ & $\checkmark$ & $\checkmark$ & $\checkmark$ \\
\hline Transient occupancy tax & & & $\checkmark$ & & $\checkmark$ \\
\hline Business-license tax & & & $\checkmark$ & & $\checkmark$ \\
\hline Cap-and-trade program & & $\checkmark$ & & & \\
\hline Franchise agreements (e.g., utilities) & & & & & $\checkmark$ \\
\hline
\end{tabular}

a For example, advertising revenue.

\subsection{STREETS AND ROADS: LOCAL, STATE, AND FEDERAL CONTRIBUTIONS}

Across all levels of government, the total funding for California's transportation system in fiscal year 2018-2019 has been reported at approximately $\$ 35$ billion dollars. ${ }^{15}$ Local 
governments contributed just shy of one half of this amount. The state contributed approximately one-third of the total, and the federal government provided the remainder.

Because funding city streets and county roads is at the heart of every city and counties' transportation responsibilities, we looked in detail at how contributions from different levels of government have evolved over the past two decades.

Figure 1 presents the total revenue made available by federal, state, and local governments for streets and roads across a 20-year time period in nominal dollars, Figure 2 shows the same data adjusted to the equivalent of 2020 dollars, and Figure 3 shows the data in terms of the percent contributed annually by each level of government. ${ }^{16}$

From a first glance at Figure 1, the total amount of revenue available over the two-decade span may look to have been growing at a healthy rate, but that first impression is misleading. In nominal dollars total revenue has roughly doubled, from approximately $\$ 4$ billion to $\$ 9$ billion, but once the values are adjusted for inflation, the growth is only about $50 \%$, from roughly $\$ 6$ billion to $\$ 9$ billion (Figure 2). During that same period the number of licensed drivers in California grew $28 \%$, roadway miles grew $5 \%$, and the number of bridges grew $9 \%$, expanding the set infrastructure to be maintained. ${ }^{17}$ Further, during that period many portions of the state's transportation infrastructure reached the end of its functional lifespan and needed major rehabilitation. As noted earlier, the League of California Cities estimated that expenditures for local streets and roads would need to be increased by $\$ 64$ billion over the next ten years in order to achieve a state of good repair. ${ }^{18}$

\section{Figure 1. Billions of Nominal Dollars Available for Roads and Streets, by Level of Government, 1999-2019}

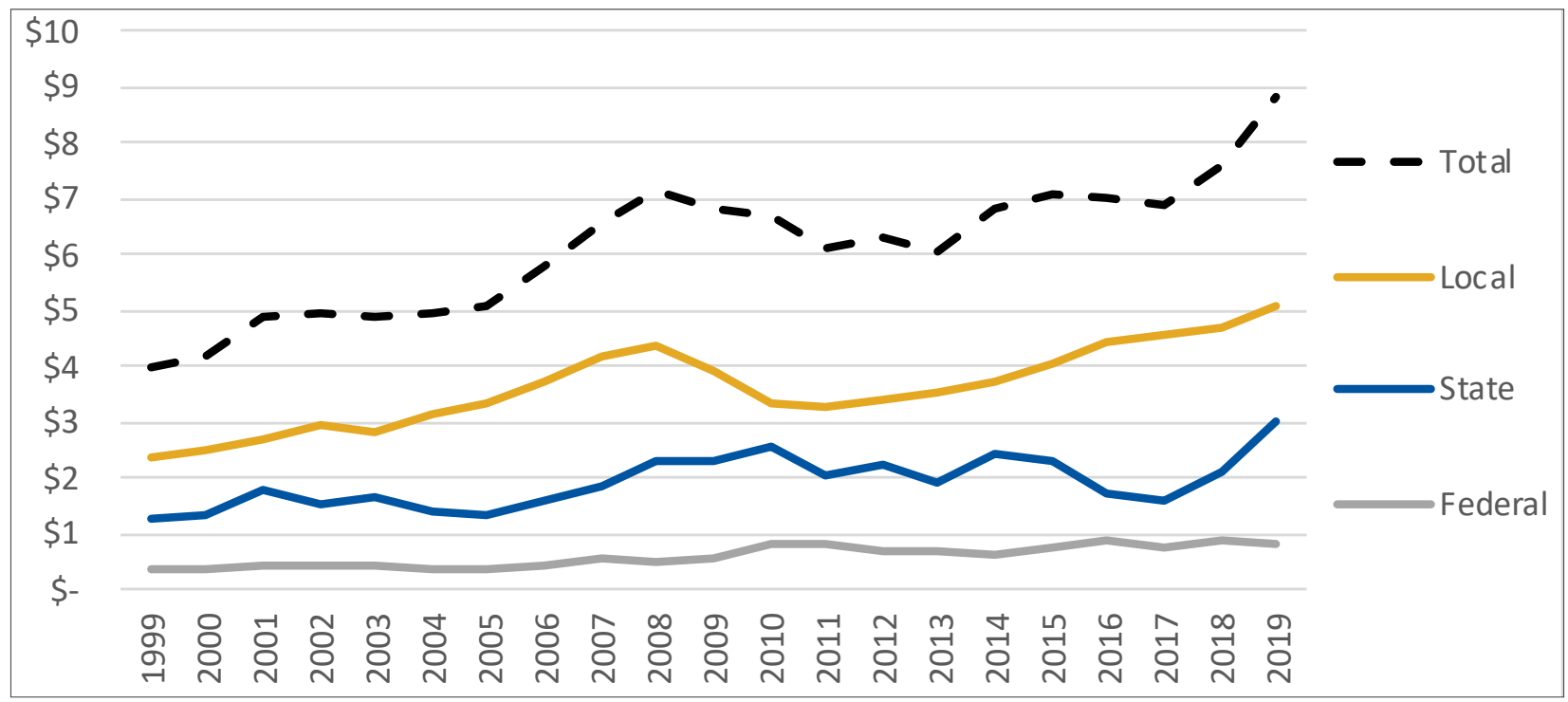

Sources: California State Controller's Office, "California State Controller's Office Local Government Financial Data," accessed May 26, 2020, https://bythenumbers.sco.ca.gov/; California State Controller's Office, "Streets and Roads Annual Report Publications," accessed May 26, 2020, https://sco.ca.gov/ard locrep streets.html; CoinNews Media LLC, "US Inflation Calculator," accessed May 26, 2020, https://www.usinflationcalculator.com/. 
Figure 2. Billions of 2020 Dollars Available for Roads and Streets, by Level of Government, 1999-2019

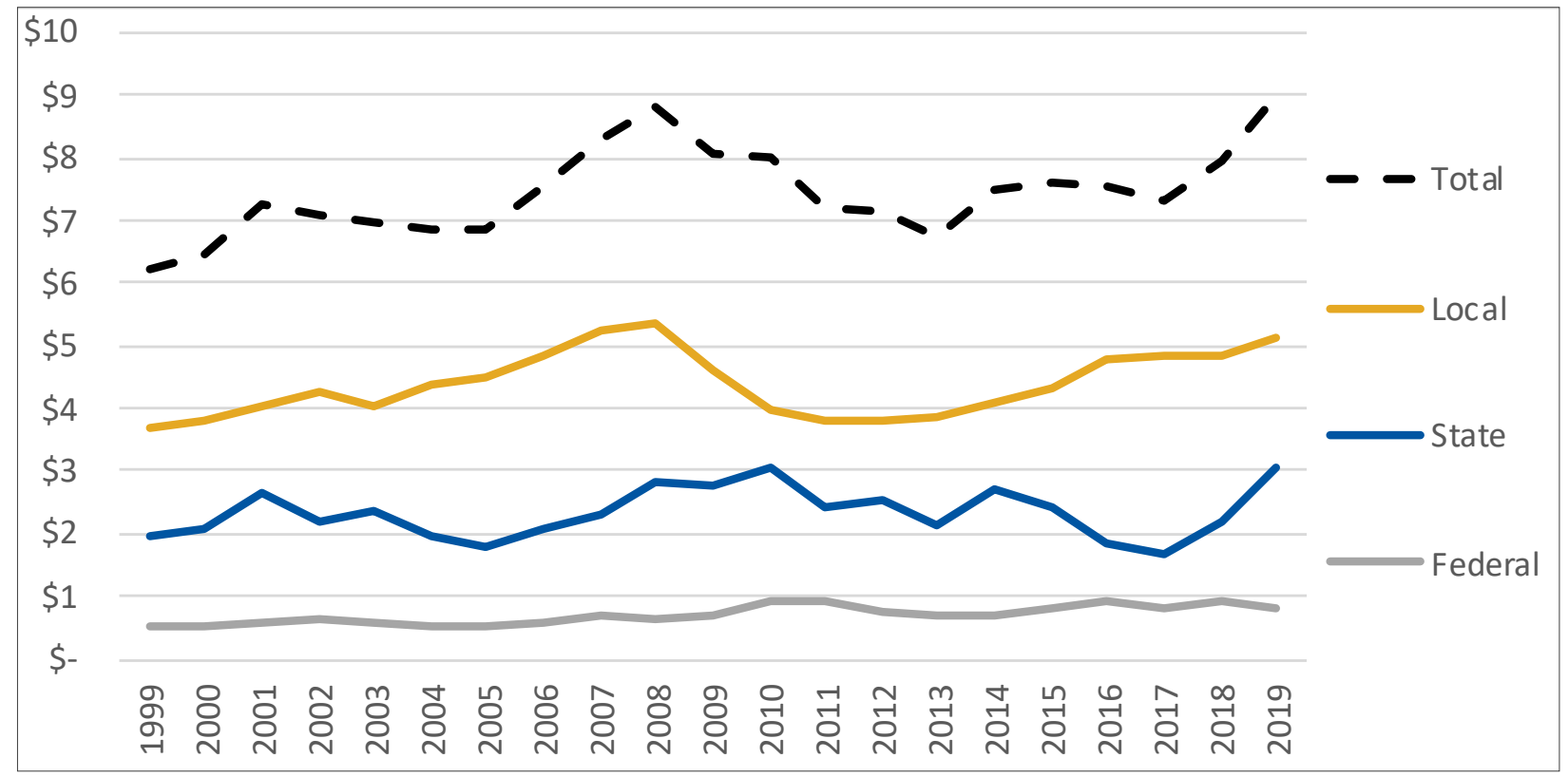

Sources: "California State Controller's Office Local Government Financial Data," California State Controller's Office, accessed May 26, 2020, https://bythenumbers.sco.ca.gov/; "Streets and Roads Annual Report Publications," California State Controller's Office, https://sco.ca.gov/ard_locrep_streets.html. 


\section{Figure 3. Percent of Revenue for Roads and Streets Provided by Each Level of Government, 1999-2019}

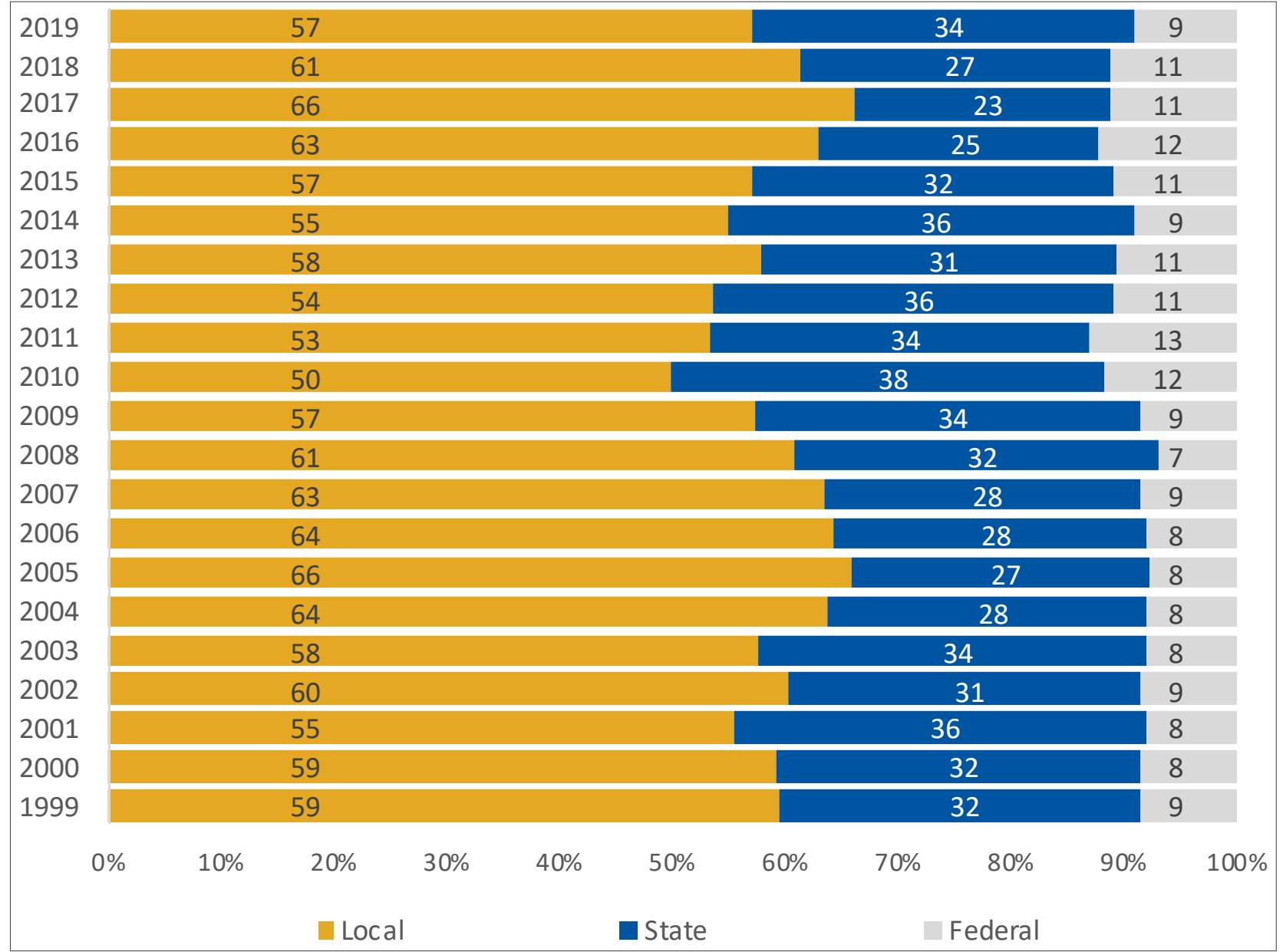

Sources: California State Controller's Office, "California State Controller's Office Local Government Financial Data," https://bythenumbers.sco.ca.gov/; California State Controller's Office, "Streets and Roads Annual Report Publications," May 26, 2020, https://sco.ca.gov/ard locrep_streets.html.

Local government revenue sources have consistently provided the majority of funds for streets and roads. Local contributions ranged from one-half to two-thirds of total annual revenue. In nominal dollar terms, the local contribution has, for the most part, steadily increased since 1999. In 1999, locals were generating $\$ 2.3$ billion annually, but by 2019 they were contributing $\$ 5.1$ billion. The one exception to this steady increase occurred during the years of the Great Recession, from late 2007 through mid-2009. During this period, local contributions for roads and streets fell sharply, in great part due to reduced sales revenues.

The relative contribution from state sources has fluctuated throughout the twenty years, ranging from $23 \%$ to $38 \%$ of total revenue. The nominal dollar value over that same period ranged from a low of $\$ 1.26$ billion in 1999 to a high of $\$ 2.99$ billion in 2019. Between 2014 and 2017, state transportation revenue fell notably, a slide that was reversed with the passage of Senate Bill 1 (SB1): The Road Repair and Accountability Act. SB1 raised fuel tax rates and imposed new annual vehicle registration fees. Collectively, these taxes and fees are projected to raise $\$ 54$ billion over a decade, with half going to cities and counties. ${ }^{19}$ The impact of SB1 has been immediate, as Figure 1 shows; the state contribution grew from 
$\$ 1.55$ billion in 2017 to $\$ 2.09$ billion in 2018 , a $74 \%$ increase. The upward trend continued in 2019 , to over $\$ 3$ billion.

The federal contribution to funding California's streets and roads has been modest throughout the two decades, fluctuating between $7 \%$ and $13 \%$. In nominal dollar terms, the federal government contributed $\$ 0.34$ billion in 1999 , with revenues growing more or less steadily to $\$ 0.81$ billion in 2019. During this period, there was one larger jump in expenditures in 2009 and 2010, when additional federal funds were disbursed to states through the American Recovery and Reinvestment Act. ${ }^{20}$

\subsection{PUBLIC TRANSIT: LOCAL, STATE, AND FEDERAL CONTRIBUTIONS}

Figures 4,5 , and 6 present data on the sources of revenue for California's public transit operators from 2003 to 2017 . Figure 4 shows the nominal value of revenue raised by each level of government, as well as from passenger fares, and Figure 5 shows the same data adjusted for inflation. Figure 6 shows the percent of total annual revenue contributed by each source. (Table A2, in Appendix A, presents the data used to construct the figures.)

Total revenue has grown from about $\$ 4$ billion to $\$ 8$ billion. Revenue from every level of government has grown slightly throughout the period, with the lowest increase in state funds.

The relative size of the contributions each source makes to the total revenue has changed little over time. The local contribution has been the largest, hovering around $50 \%$. Passenger fares have raised roughly a quarter of revenues, federal revenues have hovered around $20 \%$, and the state's contribution has been the smallest, providing from between just $2 \%$ and $8 \%$ of annual revenues.

Figure 4. Billions of Nominal Dollars Available for Public Transit, by Level of Government and By Fares, 2003-2017

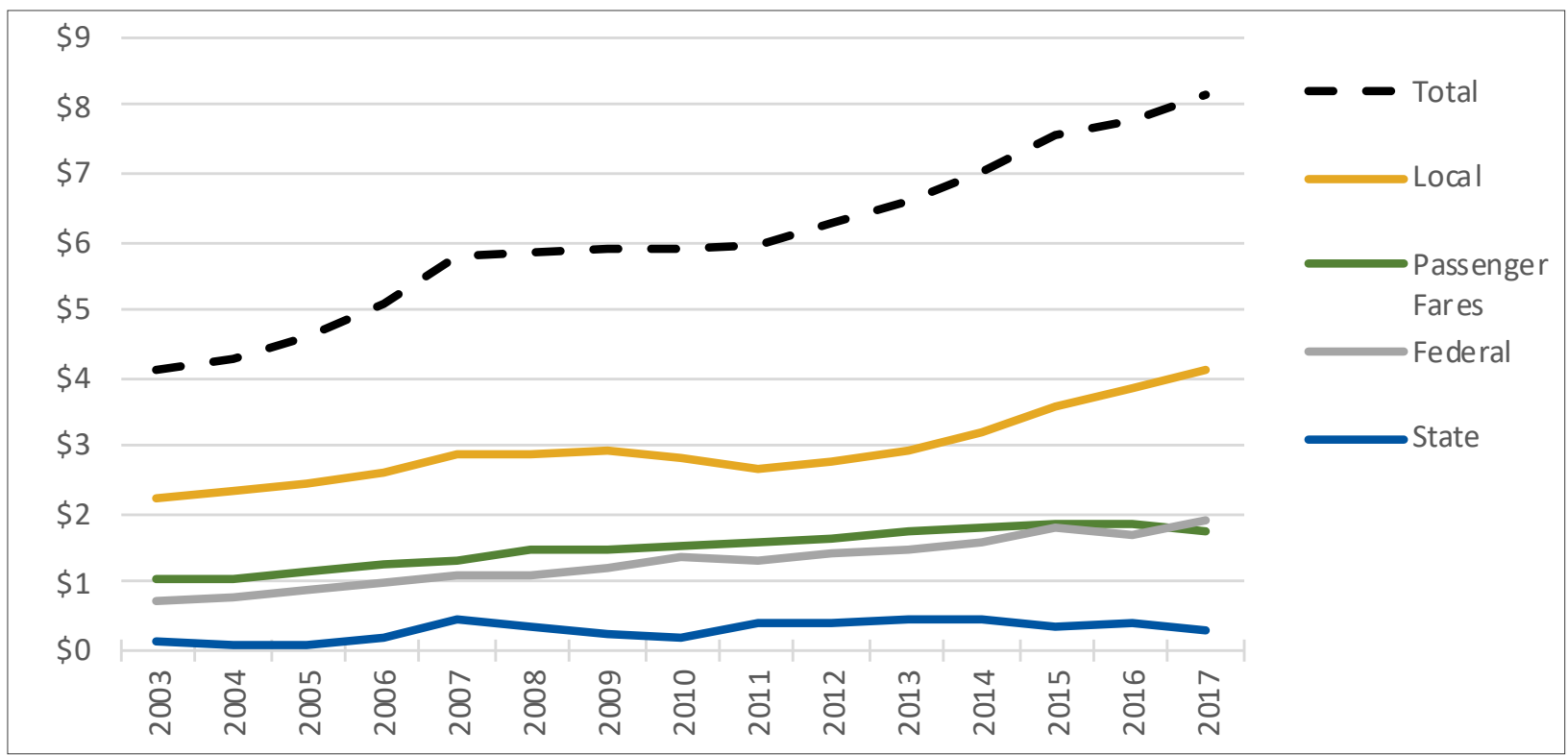

Source: California Transit Association, "Transit Data: An Interactive Repository of Facts and Figures on California Public Transit," 2021, https://caltransit.org/about/transit-datal. 
Figure 5. Billions of 2020 Dollars Available for Public Transit, by Level of Government and by Fares, 2003-2017

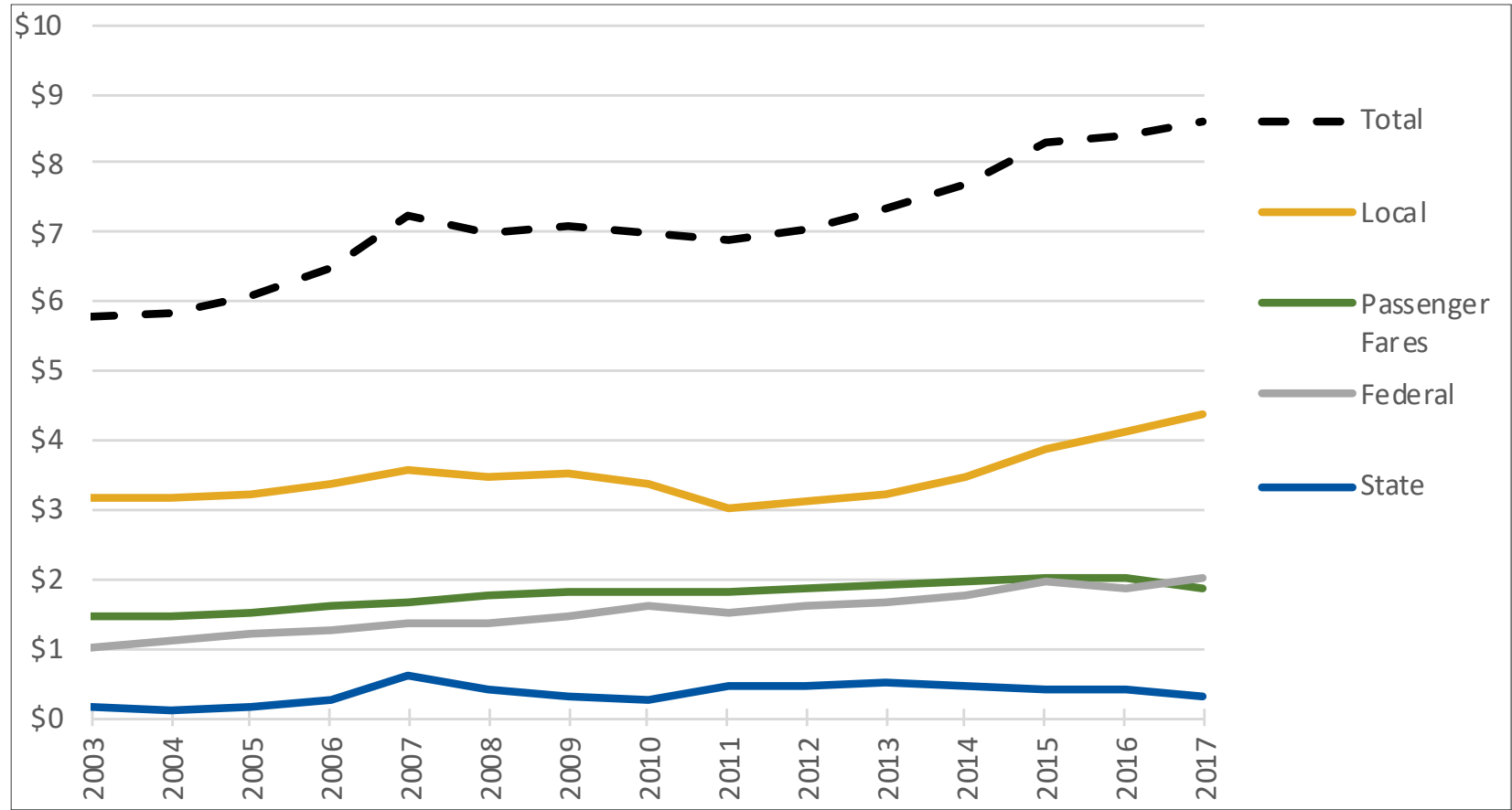

Source: California Transit Association, "Transit Data: An Interactive Repository of Facts and Figures on California Public Transit," 2021, https://caltransit.org/about/transit-data/. 
Figure 6. Percent of Revenue for Public Transit in Provided by Each Level of Government and By Fares, 2003-2017

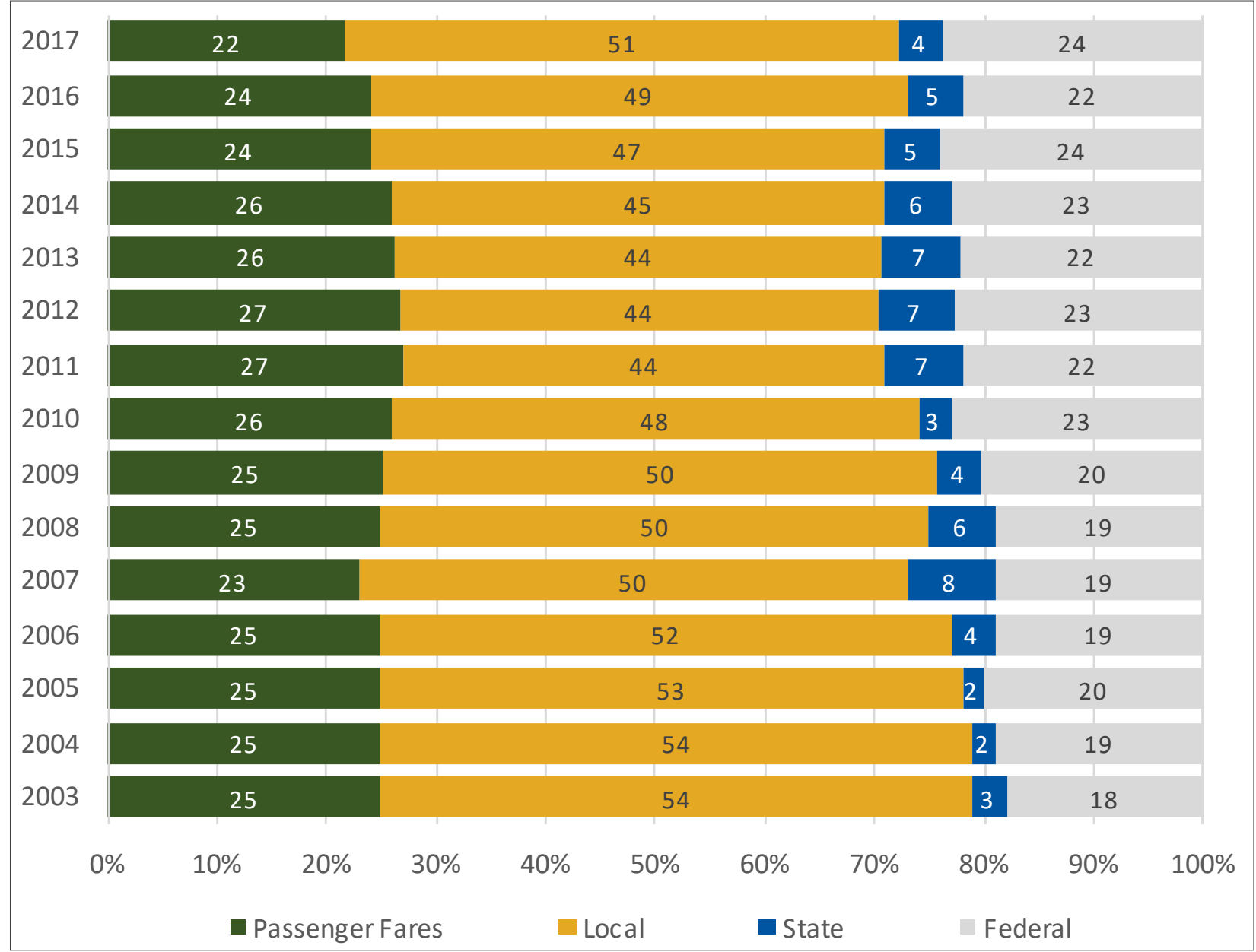

Source: California Transit Association, "Transit Data: An Interactive Repository of Facts and Figures on California Public Transit," 2021, https://caltransit.org/about/transit-data/. 


\section{FEDERAL REVENUE SOURCES}

This chapter describes the main federal sources of revenue that fund the Highway Trust Fund (HTF), the principal source of federal transportation revenue. ${ }^{21}$ The HTF is composed of two sub-accounts: the Highway Account, which funds highways and bridges, and the Mass Transit Account, which funds capital expenditures for public transit such as bus, rail, and ferry systems. Funds provided by the federal government are distributed to individual states, largely based on allocation formulas established by legislation.

The HTF has traditionally been funded through excise taxes imposed on the sale of gasoline and diesel motor fuels, sales of truck, trailers, and truck tires, and an annual weight fee on heavy vehicles. Taxes on fuels account for more than $80 \%$ net total deposits. ${ }^{22}$ Since 2008, the federal government has transferred general fund revenue to the HTF to main solvency. These transfers have filled the gap between the amounts allocated and tax revenue collected. ${ }^{23}$

\subsection{MOTOR FUEL EXCISE TAX}

\begin{tabular}{ll}
\hline Tax base: & Gallons of motor fuel \\
Rate: & $\begin{array}{l}18.4 \text { cents per gallon (gasoline); } 24.4 \text { cents per gallon (diesel); separate rates } \\
\text { for special fuels }\end{array}$ \\
Total revenue (national): & $\$ 37.7$ billion (FY 2019) $)^{24}$ \\
Revenue restricted to: & Highway Trust Fund \\
\hline
\end{tabular}

\subsection{HEAVY TRUCK AND TRAILER SALES TAX}

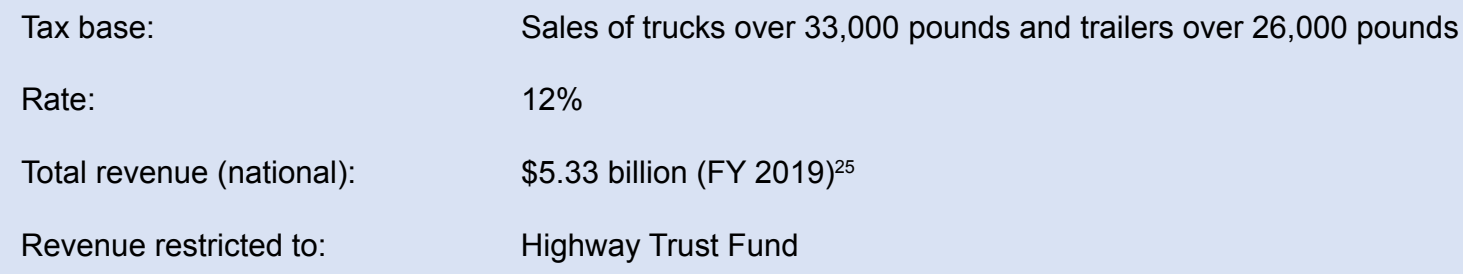

Revenue restricted to:

Highway Trust Fund

\subsection{EXCISE TAX ON HEAVY-DUTY TIRE SALES}

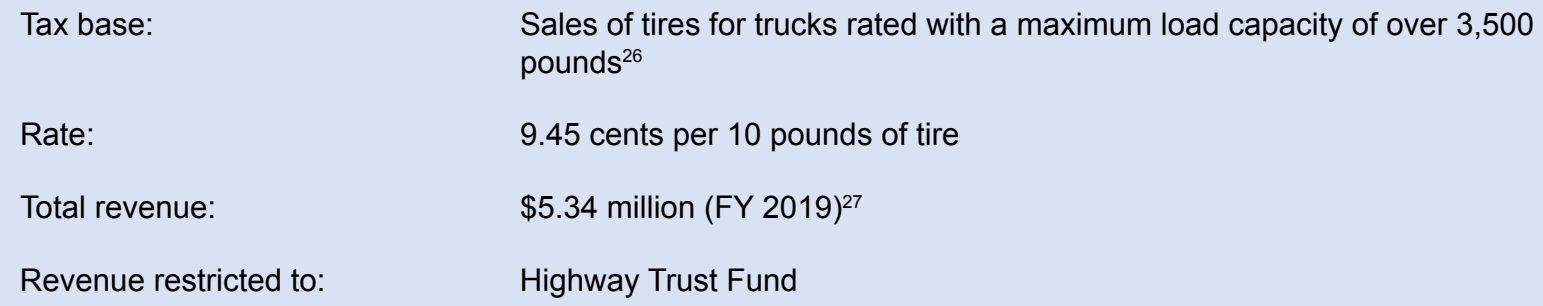




\section{Federal Revenue Sources}

\subsection{HEAVY VEHICLE USE TAX}

Tax base:

Rate:

Total revenue:

Revenue restricted to:
Trucks with a gross vehicle weight of over 55,000 pounds

$\$ 100$, plus $\$ 22$ for every 1,000 pounds over the maximum vehicle weight (annual)

$\$ 1.29$ billion (FY 2019)28

Highway Trust Fund 


\section{STATE REVENUE SOURCES}

This chapter presents those state taxes and fees for which some portion of the revenue is dedicated for local transportation purposes. Excluded are two major categories of fees paid by transportation system users that are not allocated directly for local transportation purposes: the Vehicle License Fee (VLF) and the state's base vehicle registration fees. Revenue from the VLF is deposited in the state's general fund, and a portion is transferred to local governments as general fund revenue. As for the base vehicle registration fees, revenue from these primarily funds the California Department of Motor Vehicles (DMV) and California Highway Patrol (CHP). ${ }^{29}$ Although both the DMV and CHP obviously provide services to transportation system users, neither agency has traditionally been considered part of the state's "transportation" expenditures.

The state relies heavily on user fees to pay for transportation, a trend that has held for over a century. In 1913, California introduced its first such tax, the Motor Vehicle Act of 1913. This act created an annual vehicle registration fee, with the rate varying according to engine horsepower. This new tax was designed to be a "user fee" that drivers paid, and the revenue was dedicated to pay off bonds issued to pay for construction of a planned 3,000-mile state highway system that had been legislatively authorized a decade earlier, in 1901. A weight-based annual registration fee on heavy commercial vehicles was adopted shortly after, in 1915. Less than a decade later, the 1923 California Vehicle Act imposed a two-cent per gallon tax on gasoline fuels.

Since those early days, the state has periodically adjusted the rates of these taxes and added other transportation user fees, including an annual vehicle license fee assessed as a percent of the vehicle's market value (seen as analogous to the property tax on land) and an excise tax on diesel fuel. ${ }^{30}$ The most recent major change took place in 2017, when SB1 raised fuel excise tax rates and added two new annual vehicle fees whose proceeds are spent on transportation functions, including at the local level. ${ }^{31}$ As discussed in the previous chapter, SB1 proved a watershed moment for local transportation, more than doubling state contributions.

\subsection{GASOLINE MOTOR FUEL EXCISE TAX}

\begin{tabular}{ll}
\hline Tax base: & $\begin{array}{l}\text { Gallons of gasoline fuel (excludes gasoline used for off-highway vehicles } \\
\text { such as agricultural vehicles and boats) }\end{array}$ \\
Rate: & $\begin{array}{l}\$ 0.511 \text { (a base excise of } 19.2 \phi \text { per gallon + an incremental "swap" tax + an } \\
\text { SB1 tax (SB1 rates to be adjusted annually, per SB1) }\end{array}$ \\
& $\$ 6.43$ billion (FY 2018-2019) \\
Total revenue: & State highways, local streets, local roads \\
Revenue restricted to: &
\end{tabular}




\subsection{DIESEL MOTOR FUEL EXCISE TAX}

Tax base:

Rate:

Total revenue:

Revenue restricted to:
Gallons of diesel fuel

$\$ 0.389$ per gallon (as of July 2021) (44 $^{34}$

$\$ 1.16$ billion (FY 2018-2019) $)^{35}$

Public transit operations and capital projects, high-speed rail development, road maintenance and rehabilitation, highway construction and improvements, and freight infrastructure improvements via various state funds ${ }^{36}$

\subsection{SALES TAX ON DIESEL FUEL}

$\begin{array}{ll}\text { Tax base: } & \text { Sales of diesel fuel } \\ \text { Rate: } & 5.75 \% \\ \text { Total revenue: } & \$ 0.90 \text { billion (estimate for } 2019)^{37} \\ \text { Revenue restricted to: } & \text { Public transit operations }\end{array}$

\subsection{TRANSPORTATION IMPROVEMENT FEE}

Fee base:

Rate:

Total revenue:

Revenue restricted to:

\section{Registered light-duty vehicles}

Currently $\$ 27-\$ 188$, depending on vehicle value (SB1 directs the state to adjust the fee in accordance with the Consumer Price Index ${ }^{38}$

$\$ 1.67$ billion (FY 2018-2019) 39

Streets and roads, highways, and public transit

\subsection{ROAD IMPROVEMENT FEE}

Fee base:

Rate:

Total revenue:

Revenue restricted to:
Light-duty, zero-emission vehicles (e.g., electric vehicles) of model years 2020 and later*

$\$ 100$ annually (rate to increase, per SB1)

$\$ 0.02$ billion (2020, estimated $)^{40}$

Road maintenance and rehabilitation 


\title{
4.6. VEHICLE WEIGHT FEE
}

Fee base:

Rate:

Total revenue:

Revenue restricted to:

\section{Commercial vehicles}

Ranges from $\$ 8-\$ 539$ for light-weight trucks, vans, and pickups with unladen weight of $8,000 \mathrm{lbs}$., charters and carriers with declared gross vehicle weight of $<10,000 \mathrm{lbs}$., and park trailers. Fees are based on unladen weight, number of axles, and electric vehicle designation.

Ranges from $\$ 332-\$ 2,064$ for commercial vehicles that weigh $10,001 \mathrm{lbs}$. or more and pay the Commercial Vehicle Registration Act of 2001 (CVRA) fees; the rates are based on a weight code and range. ${ }^{41}$

$\$ 1.2$ billion (FY 2019-2020, forecasted) $)^{42}$

Debt repayments (through the Transportation Debt Service Fund), mostly for bonds from Proposition 1B (2006) and Proposition 1A (2008)

\subsection{BRADLEY-BURNS UNIFORM LOCAL SALES AND USE TAX}

Tax base:

Rate:

Total revenue:

Revenue restricted to:
Sales of merchandise

$1.25 \%{ }^{43}$

$\$ 9.1$ billion in total, with $\$ 314$ million dedicated to local transportation projects (FY 2018-2019)

County transportation needs ${ }^{45}$

\subsection{CAP AND TRADE PROGRAM}

\author{
Source of revenue: \\ Allowances (permits) for metric tons of carbon dioxide equivalent emissions \\ Price per allowance: \\ Determined each year by auction \\ Total revenue: \\ $\$ 0.15$ billion for the Low-Carbon Transit Operations program and $\$ 0.29$ billion \\ for the Transit and Intercity Rail Capital Program (FY 2018-2019) ${ }^{46}$ \\ Revenue restricted to: \\ Auction proceeds are deposited in the Greenhouse Gas Reduction Fund, \\ which funds a variety of programs, following requirements set out in a series \\ of statutes. Current investment categories that support local transportation \\ are the Transit and Intercity Rail Capital Program and Low Carbon Transit \\ Operations Program. The program also funds other transportation programs, \\ including high-speed rail and clean vehicle technology. ${ }^{47}$
}




\section{LOCAL REVENUES: CITIES, COUNTIES, AND SPECIAL DISTRICTS}

This chapter describes the revenue instruments that California's local governments commonly use to raise dedicated transportation revenue. The specific package of measures varies greatly among the state's hundreds of local jurisdictions. There are currently 482 incorporated cities, 58 counties, 68 transit operations, 49 transportation planning districts, and dozens of other special districts in California that are all responsible for some set of transportation infrastructure and services within their jurisdictions. ${ }^{48}$

Although local entities are required to provide most of the transportation services within their jurisdictions - and must balance their budgets annually — the state imposes numerous restrictions on local entities' ability to impose taxes and fees. A 2016 guide to the state's local government finance system summarizes these limitations as follows:

- Property taxes may not be increased except with a two-thirds vote to fund a general obligation bond.

- The allocation of local property tax among a county, and cities, special districts and school districts within each county is controlled by the Legislature.

- Voter approval is required prior to enacting, increasing, or extending any type of local tax.

- Assessments to pay for public facilities that benefit real property require property owner approval.

- Fees for the use of local agency facilities and for services may not exceed the reasonable cost of providing those facilities and services.

- Fees for services such as water, sewer, and trash collection are subject to property owner majority protest. ${ }^{49}$

This chapter describes the different tax and fee options most commonly used to fund surface transportation, including details on key legislative restrictions and one or more examples of California local entities using the tax. For a few tax types we also provide an estimate of annual revenue raised state-wide, but in most cases that information is not available.

\subsection{LOCAL-OPTION SALES TAX}

Tax base:

Rate:
Sales of merchandise

Maximum $2 \%$ rate of combined taxes in any county, or more with state legislative authorization ${ }^{50}$

County taxes: $\$ 8.71$ billion (FY 2018-2019) 51 ; total state revenue from local option taxes 
Transportation-specific local-option sales taxes (LOSTs) serve as a primary revenue source for numerous counties, as well as some special districts operating transit services. ${ }^{52}$

Legislative Authority: The state permits counties and cities to impose local sales taxes, but only under a set of strict condition. To enact a sales and use tax, the proposal must first be approved by a two-thirds majority of the board of supervisors for a county or a two-thirds majority of the governing body of a city. It must then be approved by simple majority (50\%) of voters for a general tax measure or by a two-thirds majority for a specific tax, such as a LOST. The law requires that an expenditure plan be created for any tax enacted and that the tax rate be set at a multiple of $0.25 \% .^{53}$ The statutory maximum of a combined transaction and use tax rate in any California county is limited to two percent. ${ }^{54}$

Permitted Expenditures: Local sales tax revenue can be used for a variety of purposes, but there is a higher legal barrier for special purpose taxes. For sales tax measures that contribute to a local government's general fund, the measure requires a simple majority $(50 \%)$ to pass. However, a supermajority (two-thirds) is required to approve a sales tax measures where the local government will earmark revenue for specific purposes, such as transportation projects.

Example: In 2016, the Santa Clara Valley Transportation Authority placed Measure B on the ballot, asking voters to approve a $0.5 \%$ sales tax to fund transportation-related projects related to bicycle and pedestrian safety, public transit accessibility, and highway congestion. The measure was approved by nearly $72 \%$ of the voters, exceeding the supermajority threshold required for transportation-specific sales tax proposals. ${ }^{55}$

\subsection{COUNTY TRANSPORTATION PROJECT FEE (VEHICLE REGISTRATION FEE)}

Fee base:

Rate:
Registered vehicles within a participating county

$\$ 10$ per vehicle

Counties may partner with the DMV to collect a $\$ 10$ County Transportation Project Fee (CTPF) in conjunction with collection of the state's vehicle registration fees. Currently, five counties in the San Francisco Bay Area collect a CTPF. ${ }^{56}$ The revenue is spent on local transportation programs. 


\section{Table 3. California Counties with a CTPF Registration Charge}

\begin{tabular}{|c|c|c|c|c|}
\hline County & Legislation & $\begin{array}{l}\text { Revenue/year } \\
\text { (estimated) }\end{array}$ & Spending purposes & Eff. date \\
\hline Alameda & Measure $\mathrm{F}$ & $\$ 11$ million & $\begin{array}{l}\text { Local road improvement, traffic congestion relief, } \\
\text { local transportation technology, and pedestrian and } \\
\text { bike safety }\end{array}$ & $5 / 2 / 11$ \\
\hline Marin & Measure B & $\$ 2.3$ million & $\begin{array}{l}\text { Local streets and pathways maintenance, senior } \\
\text { and disabled persons transit, and congestion and } \\
\text { pollution reduction }\end{array}$ & $5 / 2 / 11$ \\
\hline San Francisco & Proposition AA & $\$ 5$ million & $\begin{array}{l}\text { Street repair and reconstruction, pedestrian safety, } \\
\text { transit reliability, and mobility improvements }\end{array}$ & $5 / 2 / 11$ \\
\hline San Mateo & Measure M & $\$ 6.7$ million & $\begin{array}{l}\text { Local streets and roads and county transportation } \\
\text { programs }\end{array}$ & $5 / 5 / 11$ \\
\hline Santa Clara & Measure $B$ & $\$ 14$ million & $\begin{array}{l}\text { Local transportation improvements, including pothole } \\
\text { repair, paving, traffic control signals. Matching state/ } \\
\text { federal funds }\end{array}$ & $5 / 2 / 11$ \\
\hline
\end{tabular}

Sources: "Alameda County Transportation Improvement Measure Expenditure Plan," Alameda County Transportation Commission, published December 2018, https://www.alamedactc.org/wp-content/uploads/2018/12/VRF-

Expenditure Plan-1.pdf; "Measure B - Marin County Vehicle Registration Fee," Transportation Authority of Marin, published August 2017, https://www.tam.ca.gov/wp-content/uploads/2017/08/Measure-B-VehicleRegistrationFee. pdf; "Prop AA Vehicle Registration Fee," San Francisco County Transportation Authority, Accessed March 6, 2020, https://www.sfcta.org/funding/prop-aa-vehicle-registration-fee; "Measure M Implementation Plan," City/County Association of Governments of San Mateo County, Amended May 10, 2012, https://www.ccag.ca.gov/wp-content/ uploads/2014/06/Measure-M-Implementation-Plan May2012Amendment-FINAL.pdf: "2010 \$10 Vehicle Registration Fee," Valley Transportation Authority, accessed March 6, 2020, https://www.vta.org/projects/funding/2010-10-vehicleregistration-fee.

Legislative Authority: The authority to impose a CTPF is granted through California Senate Bill 83, which was approved in 2009. County transportation agencies may impose a maximum $\$ 10$ registration for transportation-related programs, subject to voter approval. ${ }^{57}$ Typically special taxes require a supermajority for passage, but CTPFs only require a simple majority due to the provisions in SB83. A county transportation agency may directly coordinate with the Department of Motor Vehicles to set up a contract for the collection of a CTPF and is responsible for any initial program setup costs.

Permitted Expenditures: CTPF revenue must be spent for transportation projects within the taxing jurisdiction and the governing body of the county transportation agency must adopt an expenditure plan detailing how the revenue will be allocated. ${ }^{58}$ Permitted transportationrelated programs include congestion and pollution mitigation programs, and revenues may also be used to provide matching funds for programs funded by state obligation bonds. ${ }^{59}$

Example: San Mateo County adopted a County Transportation Project Fee in November of 2010 through Measure M, which went into effect in May 2011. In fiscal year 20182019 , the county reported $\$ 7.8$ million dollars of revenue collected from Measure M. After deducting administrative and DMV fees, the available revenue for transportation programs totaled $\$ 7.4$ million dollars. ${ }^{60}$ 


\subsection{PARKING FEES}

Fee base:

Rate:
Vehicle parking

Various

A local authority may charge fees to users who park their vehicles on public property. Parking fees are often treated as a user tax, such as when motorists are charged for time spent at a curb space or parked in an off-street garage.

Legislative Authority: Under California Vehicle Code 22508(a), cities have the authority to establish parking meter zones by ordinance, which requires a majority vote by all members of the governing body.

Permitted Expenditures: Revenue is typically deposited in the agency's general fund and may be spent for any purpose.

\subsection{TOLLS ON BRIDGES AND ROADS}

$\begin{array}{ll}\text { Fee base: } & \text { Vehicle passage } \\ \text { Rate: } & \begin{array}{l}\text { Charge per vehicle, with rate based on number of passengers, vehicle axles, } \\ \text { and/or congestion patterns }\end{array}\end{array}$

Tolls are user fees charged to drivers for passage on roads, bridges, and highways. Toll facilities are typically operated by regional transportation agencies but must be approved through the California Transportation Commission (CTC) at the state level. Fees are collected via toll facilities or by electronic transponder and can be fixed or varied based on congestion patterns. California contains eight bridges with tolls (all located in Northern California) and several dedicated toll roads and express lanes across the state (see Table 4). 
Table 4. Entities Operating Tolled Facilities in California

\begin{tabular}{lll}
\hline Governing authority & Facility & Pricing model \\
\hline $\begin{array}{l}\text { Los Angeles County Metropolitan } \\
\text { Transportation Authority }\end{array}$ & 10/110 Express Lanes & Variable based on traffic \\
$\begin{array}{c}\text { San Diego Association of } \\
\text { Governments }\end{array}$ & SR-125 South Bay Expressway & Fixed based on distance \\
$\begin{array}{c}\text { San Diego Association of } \\
\text { Governments }\end{array}$ & I-15 Expressway & $\begin{array}{c}\text { Variable based on traffic and } \\
\text { distance }\end{array}$ \\
$\begin{array}{c}\text { Orange County Transportation } \\
\text { Authority/Riverside County }\end{array}$ & 91 Express Lanes & $\begin{array}{c}\text { Variable based on day, time of day, } \\
\text { and direction }\end{array}$ \\
$\begin{array}{c}\text { Sransportation Commission } \\
\text { Autho Clara Valley Transportation }\end{array}$ & SR-237 Express Lanes & Variable based on traffic \\
$\begin{array}{c}\text { Alameda County Transportation } \\
\text { Commission }\end{array}$ & I-580 Express Lanes & Variable based on traffic \\
$\begin{array}{c}\text { Sunol Smart Carpool Lane Joint } \\
\text { Powers Authority }\end{array}$ & I-680 Express Lanes & Variable based on traffic \\
$\begin{array}{c}\text { Golden Gate Bridge, Highway and } \\
\text { Transportation District }\end{array}$ & Golden Gate Bridge & Fixed pricing \\
$\begin{array}{c}\text { Bay Area Toll Authority } \\
\text { Antioch, Benicia-Martinez, }\end{array}$ & Fixed pricing \\
\hline & $\begin{array}{l}\text { Carquinez, Dumbarton, San Mateo- } \\
\text { Hayward, Richmond- San Rafael, }\end{array}$ & \\
\hline
\end{tabular}

Legislative Authority: Regional transportation agencies may apply to the California Transportation Commission (CTC) for permission to construct, operate, and maintain toll lanes or other toll facilities. Applications must satisfy several criteria, such as demonstration of improvements and completed funding plans. Agreements must also be made with the California Highway Patrol for law enforcement needs.

Assembly Bill 1467 was signed into law in 2006, allowing regional transportation agencies and Caltrans to apply for the development of high occupancy toll lanes in cooperation with the CTC. Assembly Bill 194, passed in 2015, allows the CTC to set the minimum standards for toll facilities operation and also removed earlier cap of no more than four approved toll facilities. AB194 also allows regional transportation agencies to issue bonds and use toll revenues to pay for the debts accrued from construction. ${ }^{61}$

Permitted Expenditures: Permitted expenditures are outlined in Assembly Bill 193 (Section 149.7, paragraph 4), which state that funds may be used for the operational costs of the toll facility including maintenance, repairs, improvements, and bond repayments. Revenue may also be used for transportation improvements within the corridor, as outlined in an expenditure plan.

Examples: The largest of California's tolling entities, the Bay Area Toll Authority (BATA), collected $\$ 724.9$ million in fiscal year $2019 .{ }^{62}$ To provide additional context for revenues generated by various tolling agencies, toll revenues from LA Metro's ExpressLanes program totaled $\$ 62.8$ million, ${ }^{63}$ while the Golden Gate Bridge, Highway and Transportation District raised $\$ 152$ million the same fiscal year. ${ }^{64} A t$ the lower end of the spectrum, the Santa Clara Valley Transportation Authority generated $\$ 1.31$ million from its toll roads (FY 2019). ${ }^{65}$ 


\subsection{DEVELOPMENT IMPACT MITIGATION FEES}

Fee base:

Rate:
New development

Flat fee, determined through a nexus study

Development impact mitigation fees are assessed and charged by local agencies to offset the costs of infrastructure and facilities used for new development. In order to impose a development impact fee, local agencies must provide a nexus study to determine the relationship between the fee amount and the cost incurred through the use of public facilities to support the new development. ${ }^{66}$

Legislative Authority: Legislative authority to create and charge development impact fees is given to local agencies, defined as a county, city, charter city, school district, special district, and municipal public corporation as outlined in California Government Code 66000, also known as the Mitigation Fee Act. ${ }^{67}$ Local agencies must satisfy a series of conditions before creating an impact development fee. These conditions include identifying the amount of the fee, identifying which facilities or capital improvements are to receive the revenue, determining the relationship between the fee's use and new development, and determining the relationship between the need for the public facility and the new development. ${ }^{68}$

Permitted Expenditures: The revenue is typically spent on infrastructure improvements to increase service capacity or improve road safety, where such changes are needed to accommodate new development. The specific permitted expenditures of development impact fees are provided in California Government Code 66002, which states that revenue may be used for "[t]ransportation and transit facilities, including but not limited to streets and supporting improvements, roads, overpasses, bridges, harbors, ports, airports, and related facilities." 69 The Mitigation Fee Act does not allow development impact fees to be used for funding existing infrastructure, unless for the purpose of upgrading a public facility to accommodate the additional service needs from new development. ${ }^{70}$

Examples: The City of Irvine, located in Orange County, is home to 280,000 residents. As part of a joint-powers agreement with the county and neighboring cities, Irvine imposes development fees on residential housing to fund transportation facilities within the San Joaquin Hills and Foothill/Eastern transportation corridors. ${ }^{71}$ At a regional level, the Western Riverside Council of Governments manages the Transportation Uniform Mitigation Fee (TUMF) Program on behalf of Riverside County and those member cities and special districts that have opted into this regional development impact fee program. Since 2003, the TUMF Program has generated $\$ 897$ million in revenue to support transportation improvements. $^{72}$

\subsection{REFUSE VEHICLE IMPACT FEE}

Fee base:

Rate:
Households receiving refuse services

Annual fee charged to refuse collection operator

Refuse collection vehicles, more commonly known as garbage trucks, have significant 
impacts on local streets and roads due to their size and weight. Because of these impacts, local governments sometimes charge refuse collection companies a fee based on the calculated damage caused by their vehicles.

Legislative Authority: A local government's ability to impose regulatory fees, such as a refuse vehicle impact fee, falls under the police power of a city. According to Article XI, Section 7 of the California Constitution, a city "may enforce local, police, sanitary, and other ordinances and regulations not in conflict with general laws." Cities typically prepare a nexus study in the form of a report to estimate the amount of damage incurred by refuse collection vehicles. A city must hold a public hearing before adopting a new fee per California Government Code Section 66018.

Permitted Expenditures: The revenues generated by refuse vehicle impact fees is intended to pay costs associated with repairing and rehabilitating roadways damaged by heavy refuse vehicles.

Example: The City of San Ramon imposes a Refuse Vehicle Impact Fee through a franchise fee with Waste Management, the city's refuse collection service provider. Analysis by the City of San Ramon to justify its refuse vehicle impact fee concluded that refuse vehicles impose the same impact to pavement as over 9,000 sport utility vehicles. ${ }^{73}$ This fee is passed onto residential customers in the form of their service bill. In fiscal year 2018-2019, the Refuse Vehicle Impact Fee generated $\$ 484,991 .{ }^{74}$

\subsection{TRANSIT FARES}

Fee base:

Rate:
Public transit trips and passes

Varies by transit operator

Transit fares are user fees that riders pay when using transportation services. Fares may be charged on a per-ride basis, or for daily, weekly, monthly, or annual passes.

Legislative Authority: Each transit operator sets its own fares, with no limitations imposed by the state.

Permitted Expenditures: Transit fares are used to cover transit agency expenses, without restriction.

\subsection{PARCEL TAX}

Tax base:

Rate:
Parcels of real property (land)

Either a flat rate per parcel or a variable rate that depends on the size or use of the parcel

Parcel taxes emerged as an alternative for generating revenue from property owners after voters in 1978 approved the constitutional amendment known as Proposition 13. Proposition 13 barred local governments from imposing their own value-based property taxes, with only minor exceptions. While property taxes are assessed against the value 
of a parcel, parcel taxes set rates that are assessed against some other characteristic of the property. The parcel tax can apply a flat rate to all parcels, or the rate may vary according to property characteristics such as lot size, use type, number of dwelling units, or square foot of development. Although most commonly used to fund school districts, parcel taxes play an important role for fire and police districts and can also be used to fund transportation infrastructure.

Legislative Authority: Parcel taxes were originally authorized in California Proposition 13 (1978). Since, a series of other propositions and court cases have further refined how these taxes must be approved and also imposed a requirement for supermajority approval from local voters. ${ }^{75}$

Permitted Expenditures: The revenue is earmarked for a specific purpose. ${ }^{76}$

Example: The Gilmore Vista County Service Area is a district located in El Dorado County. In March 2020, county supervisors placed on the ballot Measure $\mathrm{J}$, to establish a parcel tax for that district. The measure passed with $72 \%$ approval. ${ }^{77}$ Measure $\mathrm{J}$ imposes an annual $\$ 270$ tax on improved parcels and a $\$ 120$ tax on unimproved parcels within the district. It generates an estimated $\$ 11,550$ per year for snow removal, road improvements, and maintenance services. ${ }^{78}$

\subsection{TRANSIENT OCCUPANCY TAX}

Tax base:

Rate:
Room rentals in hotels, motels, or other related properties

$2 \%-15.5 \%$ (varies by jurisdiction)

The Transient Occupancy Tax (TOT), also known as the "hotel tax" or "bed tax," is a tax commonly charged as a percentage of rent on a transient user of a hotel, motel, or property shared through a room-sharing service such as Airbnb. A transient is defined as a person with a right to occupancy for a period of 30 calendar days or less. ${ }^{79}$ The right to occupancy is established through reason of concession, permit, license, or another form of agreement.

Legislative Authority: The authority to impose a TOT comes from Section 7280 of the State of California Revenue and Taxation Code. Counties and cities can both enact a TOT. ${ }^{80}$ The process to impose a TOT follows the same procedure as a local sales tax: a governing body must approve the measure and then place it on the ballot for voter approval. General fund TOTs require a simple majority, whereas special-purpose TOTs require a supermajority.

Permitted Expenditures: There are no restrictions on how general-purpose TOT revenue is spent. For special-purpose TOTs, an expenditure plan guides how revenue is spent.

Example: The City of Ojai, located in Ventura County, depends heavily on tourism as its main source of revenue. ${ }^{81}$ In 2020, Ojai voters approved Measure C, which raised the TOT by $5 \%$, from $10 \%$ to $15 \%$. Measure $\mathrm{C}$ is expected to raise an additional $\$ 1.3$ to $\$ 1.7$ million dollars in revenue, according to the ballot measure text. Although Measure $\mathrm{C}$ revenue is deposited into the city's general fund, the city has declared street maintenance to be a 
priority project for Measure $\mathrm{C}$ funds ${ }^{82}$

\subsection{USER UTILITY TAX}

$\begin{array}{ll}\text { Tax base: } & \text { Utility services } \\ \text { Rate: } & 0 \%-11 \%\end{array}$

A user utility tax (UUT) is a tax imposed on utility services such as electricity, gas, water, sewage, and telephone. Local governments determine the rate of taxation which is then collected by utility companies through normal billing procedures. ${ }^{83}$

Legislative Authority: User utility taxes can be imposed at either the city or county level. ${ }^{84}$ These taxes also follow the legislative requirements outlined in Proposition 13 (1978) and Proposition 218 (1996), which requires that voters approve all taxes and charges to property owners. ${ }^{85}$ The vast majority of existing UUTs are general taxes, but they may also be created as a special tax.

Permitted Expenditures: The permitted expenditures of user utility taxes are similar to those of local sales taxes: UUTs may be general fund revenue sources or earmarked for special purposes.

Example: The Isla Vista Community Services District, located in Santa Barbara County, provides and maintains public infrastructure within its boundaries. In 2018, the district proposed an $8 \%$ tax on gas, water, electricity, sewage, and garbage disposal utilities in their service district of 23,000 residents. Voters within the district overwhelmingly voted to pass Measure R-2018, with an $83 \%$ approval rate. ${ }^{86}$ This district-level special tax is estimated to generate approximately $\$ 642,000$ dollars per year, with a portion of the funds set aside for transportation improvements, including sidewalks and lighting.

\subsection{TRANSPORTATION NETWORK COMPANY USER TAX}

\begin{tabular}{ll}
\hline Tax base: & Ride-hailing trip fares \\
Rate: & Set by local governments \\
\hline
\end{tabular}

These taxes are imposed on trips provided by transportation networking companies (TNCs) such as the ride-hailing firms Uber and Lyft. The tax is assessed on the rider (customer), and the rate can be set as a percentage of the trip fee, as a flat fee on all trips, or as a fee whose rate varies with characteristics of the trip.

Legislative Authority: Although California state law largely prohibits local governments from imposing taxes directly on the TNCs or drivers, the state does not prohibit municipal governments from impose taxes on customers who take trips that originate or end within the city. ${ }^{87}$ The legal basis for these taxes is similar to that permitting local governments to charge TOTs, parking fees, and utility taxes: charter cities may levy taxes so long as these are not preempted by state or federal law. ${ }^{88}$ Despite the fact that state law did not preclude local TNC 
user taxes, in 2018 the State of California adopted A.B. 1184, which granted the City and County of San Francisco the right to tax TNC rides. However, a legal analysis suggests that A.B. 1184 was ultimately not required for San Francisco to adopt a TNC user tax. ${ }^{89}$

Permitted Expenditures: The revenue is either limited to a special purpose or deposited in the city's general fund, depending on the authorizing legislation.

Examples: In 2019, the voters of the city of San Francisco approved the state's first excise tax on trips provided by transportation network companies such as Lyft and Uber. The tax, which went into effect January 1, 2020, set a 1.5\% tax on fares for shared rides and rides in zero-emission vehicles, and $3.25 \%$ tax on fares for private rides. ${ }^{90}$ The tax is estimated raise $\$ 30$ to $\$ 35$ million dollars of annual revenue dedicated to public transportation, safety improvements, and traffic congestion reduction efforts. ${ }^{91}$ The following year, voters in the City of Berkeley approved Measure GG, which imposed a TNC user tax on rides originating within the city. Measure GG set the rate as $\$ 0.50$ for solo rides and $\$ 0.25$ for shared rides. ${ }^{92}$

\subsection{BUSINESS LICENSE TAX}

Tax base:

Rate:
Varies: gross receipts, employee headcount, square footage, etc.

Set by local governments

Cities and counties may enact business license taxes for which they determine their own rate structure. Rate structures are commonly either a percentage of gross revenue or a flat rate structure, but other options include rates based on the number of employees or square footage.

Permitted Expenditures: Depending on the authorizing legislation, the revenue is either limited to a special purpose or deposited in the city's general fund.

Example: In 2019, the City of Mountain View implemented a new form of its "business registration and license tax," which assesses employers a fee based on the number of employees. The rate per employee rises according to company size. As of 2020, the rates ranged from $\$ 75$ to $\$ 150$ per person, with the rates to be adjusted annually for inflation. ${ }^{93}$ The tax proceeds go to the city's general fund, but the Mountain View City Council passed a resolution pledging to dedicate $80 \%$ of the revenue for transportation infrastructure and services. ${ }^{94}$

\subsection{ENHANCED INFRASTRUCTURE FINANCE DISTRICTS}

Tax base:

Rate:

Revenue restricted to:
Incremental growth in property value within the district

N/A

Community infrastructure; permitted transportation uses include roads, parking facilities, and transit stations

Enhanced Infrastructure Finance Districts (EIFDs) are a tool that allows cities, counties, and 
special districts to capture incremental growth in property tax revenue within a designated district and dedicate that money for specified infrastructure uses. These districts therefore do not raise new revenue for the taxing jurisdiction, but they capture for a specific purpose revenue that would otherwise have flowed to the general funds of the taxing entity. EIFDs are a variety of Tax Increment Financing (TIF) district. They are governed by a board of local elected officials and community members living in the district. ${ }^{95}$

Legislative Authority: In 2014, California adopted Senate Bill (SB) 628, which established EIFDs as a tool to foster economic development. Subsequent legislation has expanded the purposes for which EIFD revenue may be spent, and to allow EIFDs to issue bonds.

Permitted Expenditures: Revenue must be spent on infrastructure improvements, including roads, public transit stations, and parking facilities.

Examples: In 2017, the City of West Sacramento created the first EIFD in the state. The district is located along the waterfront and covers approximately $25 \%$ of the city. Revenue obtained from the EIFD will be spent on a variety of community improvements. Over its lifetime, the district is predicted to generate $\$ 535$ million (2017 equivalent dollars). ${ }^{96}$ The City of La Verne created an EIFD to fund improvements around a planned light rail station. The district will spend the projected $\$ 33$ million in revenue on a set of designated infrastructure projects that include street improvements, pedestrian connectivity, landscaping, and lighting. ${ }^{97}$ 


\section{MOVING FORWARD: OPTIONS FOR RAISING LOCAL REVENUE}

This chapter summarizes the taxes earmarked for transportation at each level of government, describes a number of tax and fee options for raising additional revenue, and concludes with recommendations for additional research.

\subsection{A SUMMARY OF REVENUE EARMARKED FOR LOCAL TRANSPORTATION}

This report has described the wide range of taxes and fees that raise revenue dedicated for California's local authorities to spend on transportation services and infrastructure. While a certain amount of unrestricted general fund revenue also supports local transportation, the great majority of revenue comes from taxes and fees that are legally or by resolution designated for transportation.

At the state and federal levels, the systems for raising transportation funding are moderately complex. Both entities rely on motor fuel taxes to raise the majority of the revenue they transfer to local entities for transportation expenses. The federal government supplements fuel tax revenue with taxes levied on the sales of heavy-duty vehicles and their tires, plus a weight-based annual fee on heavy-duty vehicles. Neither the specific taxes nor their rates have been adjusted in decades, though in recent years Congress has supplemented these taxes with general fund revenue. As for California, the state supplements motor fuel taxes with annual vehicle registration fees, a vehicle weight fee, a small portion of state sales tax revenue, and revenue raised through the state's cap and trade program. Unlike the federal government, the state has made a number of adjustments to its transportation taxes and fees in recent years. Most notably, the cap and trade program was launched in 2013, and in 2017 the legislature approved SB1, which raised the rates on motor fuel taxes and created two new annual vehicle registration fees.

If the state and federal pictures are moderate complex, the local system is diverse and byzantine. The only constants are that virtually all local entities receive at least a small amount of state and federal earmarked transportation revenue, and the great majority of residents live in communities that have voter-approved local sales taxes earmarked for transportation. (However, even if most residents live in a county with a local transportation sales tax, the same is not true for the majority of road-miles in the state, as few of California's rural counties have approved a sales tax.) Finally, virtually all public transit operations generate at least some fare revenue, which is directly used to support transportation.

Most jurisdictions augment federal, state, and local-option sales-tax funding with other taxes and fees. For some jurisdictions, the annual transportation budget may easily incorporate a dozen or more sources, including traffic impact fees on development, community service districts, an employee headcount tax, tolls, and refuse or construction vehicle impact fees.

\subsection{LOOKING FORWARD: OPTIONS}

As local and state leaders look to the future of local transportation revenue, there are a 
number of conceptual approaches to consider, as well as specific tax types. This section lays out a variety of options, organizing them by theme. Policymakers may ultimately conclude that many of these taxes and fees are neither desirable nor feasible in California, but considering such a wide variety of options can help policymakers to identify creative new revenue sources that can meet the needs of the state's diverse local jurisdictions.

Raise the rates on existing taxes and fees already earmarked for transportation. This approach will likely be more effective if used for taxes and fees imposed on a broad base, such as motor fuel and sales taxes.

Raise the rates on taxes charged to transportation system users where the revenue is not currently earmarked for transportation and earmark the incremental new revenue for transportation. Parking and traffic citation fees are one such option. Many urban jurisdictions rely on this revenue as a key source of unrestricted general funds, so simply earmarking existing fee proceeds is unlikely to be realistic. However, some urban communities are considering variable parking rates as a congestion management strategy, and part of such a plan could include earmarking a portion of the incremental revenue for improvements to non-driving modes of transportation. Another example would be to add a supplementary sales tax to vehicle purchases and designate the revenue for transportation purposes. For example, in 1989, the State of North Carolina introduced a "Highway Use Tax" of 3\% of the purchase price for any vehicle. The money is deposited into the state's Highway Trust Fund and can be used only for transportation purposes. As of 2020, Highway Use Tax revenues make up 54\% of the North Carolina Department of Transportation's revenues. ${ }^{98}$

Charge a tax on vehicle-based services that have expanded exponentially in recent years. Two examples of these services are ride-hailing and e-commerce delivery. The private companies running these services rely on public infrastructure to generate their profits, and they also impose costs on the road system, especially in congested areas. Communities may wish to tax some portion of the value that these firms generate, and earmark that revenue for transportation. A few cities have already done this with ridehailing trips-San Francisco, Berkeley, Chicago, and New York are among them-but most California cities have not. ${ }^{99}$

California local governments do not currently tax e-commerce deliveries, although a few have internally discussed the option. Legislators in both North Carolina and New York State have proposed this type of fee. In December 2020, a New York State Assembly bill was introduced that would have authorized New York City to assess a fee of $\$ 3$ per box on e-commerce deliveries, with the revenue to be dedicated to the Metropolitan Transportation Authority. The bill would reduce the impact of the fee on low-income residents by waiving the charge on deliveries of food or medical supplies, among other provisions. ${ }^{100}$ In 2021 , the North Carolina FIRST Commission released a report that proposed a "Road Impact Fee" on e-commerce deliveries. The fee rate would be structured to match existing sales tax rates of $4.75 \%$ at the state level and $2.25 \%$ at the local level. The Commission's study estimated that this new fee would generate roughly $\$ 890$ million over ten years. ${ }^{101}$

Adopt a mileage fee to replace or augment motor fuel taxes. Mileage fees, also known 
as road-user charges or vehicle miles traveled (VMT) fees, are distance-based charges. They are widely considered to be a promising alternative to motor fuel taxes, since the latter will become less effective as a growing share of the fleet becomes highly fuel efficient or uses no motor fuel at all. ${ }^{102}$ To date, mileage fees are under study in dozens of states, and small programs have been implemented in Oregon and Utah. The State of California is currently engaged in its second mileage fee pilot program. ${ }^{103}$

While research and pilots to date have primarily examined mileage fees as a state or federal revenue tool, it is theoretically possible to layer local charges on top of those systems. For example, if the State of California were to collect a mileage fee using a technology that records the location of travel, then the state could permit local governments to charge additional fees for travel within their jurisdictions as a whole, on certain facilities, or at certain times of day.

Local motor fuel taxes have set a precedent for the idea of local mileage fees. Currently, over a dozen states permit cities or counties to adopt a local motor fuel tax, ${ }^{104}$ and new taxes have been imposed as recently as 2020. For example, in 2020 the voters of Missoula County, Montana, adopted a \$0.02-per-gallon local option gasoline tax. Missoula is the first county in Montana to have taken advantage of this option, even though state lawmakers passed authorizing legislation in $1979 .{ }^{105}$ Also in 2020 , the city council of Fairbanks, Alaska, passed a gas tax in the form of a 5-cent excise tax on wholesale transactions of gasoline. ${ }^{106}$ Finally, Virginia's transportation districts benefit from a tax placed on every gallon of gas and diesel fuel sold within a county or city belonging to a transportation district. The rate is $2.1 \%$ of the statewide average distributors' price of fuel, and revenues are earmarked for commuter rail services and transit authority capital projects and operations. ${ }^{107}$

Although no California municipality has ever collected a local gasoline tax, voters have approved one such tax. In 1980, just over $50 \%$ of voters in the City of San Francisco approved a one-cent-per-gallon local gasoline tax. Ultimately, however, the city never attempted to implement the measure because of legal uncertainty over whether state law would require a simple majority or two-thirds majority to approve such a tax.

Another variation on mileage fees would charge different rates for different types of vehicles, such as a lower rate for less polluting vehicles or a higher rate for heavy vehicles that impose more roadway damage. Precedent for the idea of charging heavy vehicles by the mile comes from other states that impose weight-distance fees on heavy vehicles. Variants on this tax are found in New York, Kentucky, Oregon, and New Mexico. For example, Oregon collects a weight-mile tax on heavy vehicles over 26,000 pounds, in lieu of a motor fuel tax. ${ }^{108}$ New Mexico assesses a "trip tax": a fee collected on commercial vehicles not registered in the state that are used for the transportation of persons, property, or merchandise within the state. The trip tax is collected at the various entry ports of the state and revenues are placed into the Road Fund for maintenance and repair costs of the state's public highways. ${ }^{109}$

Tax the electricity used to fuel vehicles. As more and more vehicles rely on electricity, it may become realistic to impose a tax on the electricity they use. Such a tax could be couched as a direct substitute for the fuel taxes paid by internal combusion vehicles. 
Although such an e-fuel tax does not exist in the United States, Minnesota legislators have introduced a bill for a so-called "electric fuel tax" that would charge 5.1 cents per kilowatt hour of fuel used to charge an electric vehicle. ${ }^{110}$

Charge property owners monthly "utility" fees for roadway services. Transportation utility fees (TUFs) assess a monthly fee on commercial and residential property occupants, using the proceeds to pay for local streets and roads. A study from 2016 identified 34 cities that impose TUFs. Cities establish the rates in a variety of ways, including a flat rate for all property occupants and rate-scales based on estimated trips generated by the property. ${ }^{111}$

Tax utilities that embed infrastructure in or along roadways. In Virginia, public rightof-way use fees are fees imposed on consumers for cables that provide communication services. For the counties of Arlington and Henrico, which opted to keep jurisdiction over their roads in 1932, $10 \%$ of these use fees must be applied to transportation system maintenance and construction. ${ }^{112}$ In Florida, HB 7175 was passed by the Florida legislature in 2014 which allows the Department of Transportation to earn revenue from leasing department-owned land for the operation of wireless telecommunication facilities. Proceeds from these lease agreements are placed into the State Transportation Trust Fund. ${ }^{113}$

Given that local entities have such varied infrastructure and services, travel patterns, and tax bases, state policymakers may wish to take the approach of permitting-and encouraging - an expanded range of revenue tools from which local entities pick and choose. For example, a county with a small population but large volumes of heavy-vehicle through traffic might be interested in a tax or fee that raises money from those system users to compensate for wear and tear on pavement. In contrast, a dense urban area might be more interested in a tax on e-commerce deliveries or tolling, and residential suburban communities might gravitate towards some sort of fee or tax assessed on properties.

\subsection{STRATEGIES FOR IDENTIFYING THE BEST OPTIONS}

Local entities have shown great creativity in raising revenue dedicated for transportation and, as necessity arises, they will continue to do so. However, a well-reasoned and deliberative process conducted state-wide would help elected leaders make wise choices about the most appropriate tax and fee options for their communities.

One value of such a process would be to assemble the data, legal and technical analyses, and stakeholder perspectives needed to assess which options would fare well across a range of criteria, such as: ${ }^{114}$

1. Revenue generation: How much revenue will the tax or fee raise, and how stable and predictable will the revenue stream be over time?

2. Ease of implementation: What is the cost and complexity of implementing the tax or fee? For example, can the state modify existing tax administration processes, or would it be necessary to create new and complex structures?

3. Political feasibility: To what extent will elected officials, stakeholder groups, and 
the general public support the tax or fee?

4. Equity: Who will directly and indirectly bear the cost of paying the tax or fee, and who will receive the benefits of the expenditures?

5. Transportation system performance: Does the tax or fee change the way people use the transportation system in a way that improves or worsens performance?

6. Impact on larger policy goals: Will the payment of the tax or fee, as well as expenditure of the revenue, impact public policy goals beyond the transportation system, such as reducing the threat of climate change or improving social equity, public health, or economic strength?

While the implications for each of the six criteria will vary somewhat from place to place, it would be more efficient to have a single entity collect relevant information and develop appropriate analytic tools to assess the taxes and fees. This framework would provide a basis from which both the State of California itself and local entities could develop their own expanded analysis.

As one contribution towards this goal, the authors will publish a companion to this report that draws on the experience and insights from transportation experts across the state to identify promising transportation revenue strategies for California. 


\section{APPENDIX A: DETAILS ON REVENUE SOURCE BY LEVEL OF GOVERNMENT}

This appendix presents additional detail about the revenue used to create the figures in Chapter 2. Table A1 presents data on local, state, and federal contributions to local streets and roads. Table A2 presents data on the proportion of transit operator revenue contributed by fares, local, state, and federal sources.

Table A1. Revenue Available for Roads and Streets, by Level of Government, 1999-2019 (Billions of Dollars/Percent of Total)

\begin{tabular}{llcl}
\hline Year & Local & State & Federal \\
\hline 1999 & $\$ 2.35(60 \%)$ & $\$ 1.26(32 \%)$ & $\$ 0.34(8 \%)$ \\
2000 & $\$ 2.48(59 \%)$ & $\$ 1.36(32 \%)$ & $\$ 0.36(9 \%)$ \\
2001 & $\$ 2.71(56 \%)$ & $\$ 1.78(36 \%)$ & $\$ 0.40(8 \%)$ \\
2002 & $\$ 2.97(60 \%)$ & $\$ 1.53(31 \%)$ & $\$ 0.42(9 \%)$ \\
2003 & $\$ 2.82(58 \%)$ & $\$ 1.68(34 \%)$ & $\$ 0.39(8 \%)$ \\
2004 & $\$ 3.13(64 \%)$ & $\$ 1.40(28 \%)$ & $\$ 0.39(8 \%)$ \\
2005 & $\$ 3.32(66 \%)$ & $\$ 1.34(27 \%)$ & $\$ 0.39(7 \%)$ \\
2006 & $\$ 3.71(64 \%)$ & $\$ 1.61(28 \%)$ & $\$ 0.45(8 \%)$ \\
2007 & $\$ 4.13(63 \%)$ & $\$ 1.84(28 \%)$ & $\$ 0.56(9 \%)$ \\
2008 & $\$ 4.34(61 \%)$ & $\$ 2.29(32 \%)$ & $\$ 0.49(7 \%)$ \\
2009 & $\$ 3.89(57 \%)$ & $\$ 2.31(34 \%)$ & $\$ 0.58(9 \%)$ \\
2010 & $\$ 3.34(50 \%)$ & $\$ 2.57(38 \%)$ & $\$ 0.79(12 \%)$ \\
2011 & $\$ 3.27(53 \%)$ & $\$ 2.06(34 \%)$ & $\$ 0.80(13 \%)$ \\
2012 & $\$ 3.36(54 \%)$ & $\$ 2.23(35 \%)$ & $\$ 0.68(11 \%)$ \\
2013 & $\$ 3.49(58 \%)$ & $\$ 1.89(31 \%)$ & $\$ 0.65(11 \%)$ \\
2014 & $\$ 3.73(55 \%)$ & $\$ 2.45(36 \%)$ & $\$ 0.62(9 \%)$ \\
2015 & $\$ 4.01(57 \%)$ & $\$ 2.27(32 \%)$ & $\$ 0.77(11 \%)$ \\
2016 & $\$ 4.41(63 \%)$ & $\$ 1.74(25 \%)$ & $\$ 0.85(12 \%)$ \\
2017 & $\$ 4.53(66 \%)$ & $\$ 1.55(23 \%)$ & $\$ 0.77(11 \%)$ \\
2018 & $\$ 4.66(61 \%)$ & $\$ 2.09(28 \%)$ & $\$ 0.86(11 \%)$ \\
2019 & $\$ 5.05(57 \%)$ & $\$ 2.99(34 \%)$ & $\$ 0.81(9 \%)$ \\
\hline$\$ 0 u r \%)$ & &
\end{tabular}

Sources: Data for 1999 through 2017 is compiled from the California State Controller's Office's "Streets and Roads Annual Report Publications" 1999-2017 (https://sco.ca.gov/ard_locrep_streets.html); 2018 and 2019 data is from the "Streets - Revenues" and "Roads - Revenues" sections of the Local Government Financial Data portal (https:// bythenumbers.sco.ca.gov/). 
Table A2. Revenue Available for Public Transit, by Level of Government, 20032017

\begin{tabular}{lccrrc}
\hline Year & Local & Passenger Fares & \multicolumn{1}{c}{ Federal } & \multicolumn{1}{c}{ State } & \multicolumn{1}{c}{ Total } \\
\hline 2003 & $2,245,973,933$ & $1,028,511,040$ & $726,812,986$ & $128,275,864$ & $4,129,573,823$ \\
2004 & $2,326,184,293$ & $1,064,565,725$ & $805,351,703$ & $75,956,864$ & $4,272,058,585$ \\
2005 & $2,443,341,439$ & $1,145,709,621$ & $904,317,016$ & $102,089,173$ & $4,595,457,249$ \\
2006 & $2,630,752,453$ & $1,249,186,718$ & $975,928,594$ & $208,560,833$ & $5,064,428,598$ \\
2007 & $2,869,891,102$ & $1,339,326,234$ & $1,093,744,152$ & $482,735,807$ & $5,785,697,295$ \\
2008 & $2,899,313,757$ & $1,454,894,488$ & $1,124,387,513$ & $354,078,027$ & $5,832,673,785$ \\
2009 & $2,931,526,375$ & $1,496,545,960$ & $1,202,011,012$ & $252,101,849$ & $5,882,185,196$ \\
2010 & $2,841,529,760$ & $1,515,534,684$ & $1,352,635,070$ & $197,054,421$ & $5,906,753,935$ \\
2011 & $2,647,373,459$ & $1,583,703,204$ & $1,328,234,102$ & $413,580,356$ & $5,972,891,121$ \\
2012 & $2,754,473,441$ & $1,658,400,523$ & $1,410,075,649$ & $428,474,717$ & $6,251,424,330$ \\
2013 & $2,915,219,879$ & $1,741,717,286$ & $1,485,232,040$ & $464,735,682$ & $6,606,904,887$ \\
2014 & $3,197,884,039$ & $1,800,219,157$ & $1,606,831,165$ & $433,265,405$ & $7,038,199,766$ \\
2015 & $3,563,904,921$ & $1,856,829,048$ & $1,801,757,139$ & $358,239,734$ & $7,580,730,842$ \\
2016 & $3,834,744,879$ & $1,865,318,560$ & $1,710,446,804$ & $389,132,098$ & $7,799,642,341$ \\
2017 & $4,145,031,295$ & $1,770,430,585$ & $1,917,663,201$ & $311,382,889$ & $8,144,507,970$ \\
\hline
\end{tabular}

Source: California Transit Association, "Transit Data: An Interactive Repository of Facts and Figures on California Public Transit” (2021), https://caltransit.org/about/transit-data/. 


\section{ENDNOTES}

1. NCE, California Statewide Local Streets and Roads Needs Assessment: Final Report (League of California Cities, August 2021), accessed October 20, 2021 , https://www.savecaliforniastreets.org/wp-content/uploads/2021/08/Statewide-2020Local-Streets-and-Roads-Needs-Assessment-Final-8-4-21.pdf.

2. American Public Transit Association, "APTA Ridership Trends," accessed October 20, 2021, https://transitapp.com/APTA.

3. Gavin Newsom, Governor's Budget Summary 2021-22 (January 8, 2021), 250-254 and 262-2, accessed October 20, 2021, http://www.ebudget.ca.gov/2021-22/pdf/ BudgetSummary/FullBudgetSummary.pdf.

4. NCE, California Statewide Needs Assessment, 6.

5. For example: Los Angeles County Metropolitan Transportation Authority, Metro Funding Sources Guide 2020 (2020), accessed October 20, 2021, http://media. metro.net/2020/Metro-Funding-Sources-Guide-2020.pdf.

6. Self-Help Counties Coalition, "Our Members" (2021), accessed October 20, 2021, http://selfhelpcounties.org/\#members.

7. California Special Districts Association, "Special Districts: The Most Local of Local Governments" (2020), accessed October 20, 2021, https://www.twainhartecsd.com/ files/fa9dd6cd4/2020 Special Districts Guide WEB.pdf.

8. Institute for Local Government, Understanding the Basics of Municipal Revenues in California: Cities, Counties and Special Districts - 2016 Update (2016), 9, accessed October 20, 2021, https://www.ca-ilg.org/sites/main/files/file-attachments/basics of municipal revenue 2016.pdf.

9. Michael Coleman, "Chapter 5: Other Revenue Raised Locally," in The California Municipal Revenue Source Handbook, $5^{\text {th }}$ edition (League of California Cities, 2019).

10. Institute for Local Government, Basics of Municipal Revenues, 5.

11. Ibid.

12. California Senate Governance and Finance Committee, "Special District Fact Sheet" (September 2016), 5, https://sgf.senate.ca.gov/sites/sgf.senate.ca.gov/files/special district facts 2016.pdf.

13. California State Controller's Office, "Special Districts" (June 12, 2020), accessed October 20, 2021, https://publicpay.ca.gov/Reports/SpecialDistricts/SpecialDistricts. aspx? year=2018. 
14. California Special Districts Association, "Learn about Districts" (2020), accessed October 20, 2021, https://www.csda.net/special-districts/learn-about.

15. California Legislative Analyst's Office, California's Transportation System, by Mac Taylor (June 7, 2018), accessed October 20, 2021, https://lao.ca.gov/Publications/ Report/3860.

16. Figure 4 shows the same data with inflation-adjusted dollars.

17. Population data from the U.S. Census (https://www.census.gov/quickfacts/fact/ table/CA); travel and infrastructure data downloaded from the U.S. Department of Transportation, Bureau of Transportation Statistics, "State Transportation Statistics," https://www.bts.gov/product/state-transportation-statistics.

18. NCE, California Statewide Needs Assessment.

19. California Department of Transportation, "Rebuilding California" (2021), accessed October 20, 2021, http://rebuildingca.ca.gov/.

20. California Legislative Analyst's Office, "The Budget Package: 2009-10 California Spending Plan" (October 2009), accessed October 20, 2021, https://lao. ca.gov/2009/spend_plan/spending plan 09-10.aspx\#transportation.

21. To learn more about the federal Highway Trust Fund, see the following: Eno Center for Transportation, "Highway Trust Fund (HTF) Reference Page," accessed October 20, 2021, https://www.enotrans.org/htf/; Peter G. Peterson Foundation, "The Highway Trust Fund Explained" (June 27, 2018), accessed October 20, 2021, https://www.pgpf.org/budget-basics/budget-explainer-highway-trustfund; Federal Highway Administration, "Funding Federal-Aid Highways" (August 15, 2018), accessed October 20, 2021, https://www.fhwa.dot.gov/policy/olsp/ fundingfederalaid/07.cfm; Congressional Research Service, Funding and Financing Highways and Public Transit (May 11, 2020), accessed October 20, 2021, https:// fas.org/sgp/crs/misc/R45350.pdf.

22. Jeff Davis, "Highway Trust Fund 101" (Eno Center for Transportation, June 2, 2020), accessed October 20, 2021, https://www.enotrans.org/article/highway-trust-fund101/\#what-constitutes-htf.

23. Jeff Davis, "Ten Years of Highway Trust Fund Bankruptcy: Why Did It Happen, and What Have We Learned" (Eno Center for Transportation, September 5, 2018), accessed October 20, 2021, https://www.enotrans.org/article/ten-years-of-highwaytrust-fund-bankruptcy-why-did-it-happen-and-what-have-we-learned/; Carl Davis, "Federal Inaction on the Gas Tax is Costing Us Dearly" (Institute on Taxation and Economic Policy, February 26, 2020), accessed October 20, 2021, https://itep.org/ federal-inaction-on-the-gas-tax-is-costing-us-dearlyl.

24. Eno Center for Transportation, "Table TF-6 Highway Trust Fund Results 
of Operations, Fiscal Year 2019," (June 2020), 478, accessed October 20, 2021, https://www.enotrans.org/wp-content/uploads/2020/06/HTF-AnnualReports-1957-2019.pdf.

25. Ibid.

26. Jeff Davis, "If Paid for by Motor Fuels Taxes, DeFazio Bill Would Double Federal Gas Tax" (Eno Center for Transportation, June 4, 2020), accessed October 20, 2021, https://www.enotrans.org/article/if-paid-for-by-motor-fuels-taxes-defazio-billwould-double-federal-gas-taxl.

27. Eno Center for Transportation, "Table TF-6."

28. Ibid.

29. California Legislative Analyst's Office, "The 2020-21 Budget: Transportation," (February 10, 2020), accessed October 20, 2021, accessed October 20, 2021. https://lao.ca.gov/Publications/Report/4149.

30. For details about California's early transportation revenue sources, see: Mark Garrett, Anne Brown, and Martin Wachs, "Funding Transportation in California: A History of Crises," California Journal of Politics and Policy 8, no. 4 (2016).

31. Legislative Analyst's Office, "Overview of the 2017 Transportation Funding Package," by Mac Taylor (June 8, 2018), accessed October 20, 2021, https://lao. ca.gov/reports/2017/3688/2017-transportation-package-060817.pdf.

32. California Department of Tax and Fee Administration, "Annual Report 2018-2019" (June 2020), accessed October 20, 2021, https://www.cdtfa.ca.gov/formspubs/ pub306-2018-19.pdf; Brown, Garrett, and Wachs, "Fuel Tax Swap"; Robert McClelland, "The Ups and Downs of California's Gas Tax" (Tax Policy Center, November 1, 2018), accessed October 20, 2021, https://www.taxpolicycenter.org/ taxvox/ups-and-downs-californias-gas-tax.

33. California Department of Tax and Fee Administration, Annual Report of the California Department of Tax and Fee Administration (June 2020), accessed October 20, 2021, https://www.cdtfa.ca.gov/formspubs/pub306-2018-19.pdf.

34. California Department of Tax and Fee Administration, "Sales Tax Rates for Fuels" (2021), accessed October 20, 2021, https://www.cdtfa.ca.gov/taxes-and-fees/salestax-rates-for-fuels.htm.

35. California Department of Tax and Fee Administration, Annual Report, 70.

36. California Department of Transportation, Transportation Funding in California 2019 (2019), 23, accessed October 20, 2021, https://dot.ca.gov/programs/transportationplanning/economics-data-management/transportation-economics/transportation- 
funding-in-ca.

37. Asha Weinstein Agrawal, Hannah King, and Martin Wachs, The Impact of COVID-19 on California Transportation Revenue (Mineta Transportation Institute, May 2020), accessed October 20, 2021, https://transweb.sjsu.edu/research/2018-COVID-19California-Transportation-Revenues.

38. "Chapter 6. Transportation Improvement Fee," in Senate Bill 1: Transportation Funding (California), accessed October 20, 2021, https://leginfo.legislature.ca.gov/ faces/billTextClient.xhtml?bill id=201720180SB1.

39. Gavin Newsom, "Revenue Estimates," in Governor's Budget Summary-2020-21 (January 10, 2020), 241, accessed October 20, 2021, http://www.ebudget. ca.gov/2020-21/pdf/BudgetSummary/RevenueEstimates.pdf.

40. Agrawal, King, and Wachs, May 2020.

41. California Department of Motor Vehicles, "Appendix 1F - Fees," in Vehicle Industry Registration Procedures Manual, accessed October 20, 2021, https://www.dmv. ca.gov/portal/handbook/vehicle-industry-registration-procedures-manual-2/appendix1f-fees/.

42. Gavin Newsom, "Revenue Estimates," in Governor's Budget Summary - 2019-20 (January 10, 2019), 173, http://www.ebudget.ca.gov/2019-20/pdf/BudgetSummary/ RevenueEstimates.pdf.

43. California Department of Motor Vehicles, "DMV Collections 2018-2019," accessed October 20, 2021, https://www.dmv.ca.gov/portal/wcm/connect/88c7fa82-705744d1-861e-d67a9dd0d90d/dmv collections.pdf.

44. After the total sales tax is collected, $1 \%$ is redistributed to the county or city depending on what was negotiated between local governments as a source of discretionary spending, while $0.25 \%$ is allocated to county-level local transportation funds (LTFs). The Bradley-Burns tax has not always explicitly supported local transportation projects. The Transportation Development Act of 1971 created LTFs to urge counties to expand transportation services within their jurisdictions. This legislation also decreed that $0.25 \%$ of the $1.25 \%$ Bradley-Burns tax would be solely dedicated to funding the 58 LTFs across the state.

45. California Department of Tax and Fee Administration, Annual Report, 8.

46. California State Auditor, "The Bradley-Burns Tax and Local Transportation Funds" (November 30, 2017), accessed October 20, 2021, https://www.auditor.ca.gov/pdfs/ reports/2017-106.pdf; California Department of Transportation, Division of Mass Transportation, "Transportation Development Act Statutes and California Codes of Regulations" (May 2003), accessed October 20, 2021, http://actransit.org/wpcontent/uploads/board memos/34ed2e.pdf. 
47. California Air Resources Board, Annual Report to the Legislature on California Climate Investments Using Cap-and-Trade Auction Proceeds (March 2019), iii, accessed October 20, 2021, https://ww2.arb.ca.gov/sites/default/files/classic//cc/ capandtrade/auctionproceeds/2019 cci annual report.pdf.

48. California Air Resources Board, "California Climate Investments Legislative Guidance” (2021), accessed October 20, 2021, https://ww2.arb.ca.gov/resources/ documents/california-climate-investments-legislative-guidance.

49. California Department of Transportation, Transportation Funding 2019, 7.

50. Institute for Local Government, Basics of Municipal Revenues, 7.

51. "Transactions and Use Taxes - General Provisions and Definitions" in Revenue and Taxation Code (California), accessed October 20, 2021, https://leginfo.legislature. ca.gov/faces/codes displayText.xhtml?lawCode=RTC\&division=2.\&title=\&part=1.6.\& chapter=1.\&article=.

52. California Department of Tax and Fee Administration, "Quarterly Distribution of District Tax (from 2018 to Present)," accessed October 20, 2021, https://www.cdtfa. ca.gov/dataportal/dataset.htm?url=LRBQtrDistDistrictTax.

53. A few cities, such as Long Beach, impose a general-purpose sales tax from which some revenue is typically allocated each year for transportation.

54. "SB-566 Transactions and Use Tax: Maximum Allowable Rate," in Revenue and Taxation Code (California), accessed October 20, 2021, http://leginfo.legislature. ca.gov/faces/billNavClient.xhtml?bill id=200320040SB566.

55. "AB-464 Transactions and Use Taxes: Maximum Combined Rate (2015-2016)," in Revenue and Taxation Code (California), accessed October 20, 2021, https://leginfo. legislature.ca.gov/faces/billNavClient.xhtml?bill id=201520160AB464.

56. Santa Clara Valley Transportation Authority, "2016 Measure B," accessed October 20, 2021, https://www.vta.org/projects/funding/2016-measure-b.

57. California Department of Motor Vehicles, "Appendix 1A - County Fees," accessed October 20, 2021, https://www.dmv.ca.gov/portal/dmv/detail/pubs/reg hdbk/ appendix/appendix1a countycityfees.

58. "SB-83 Traffic Congestion: Motor Vehicle Registration Fees," in Vehicle Code (California), accessed October 20, 2021, http://leginfo.legislature.ca.gov/faces/ billNavClient.xhtml?bill id=200920100SB83.

59. Ibid.

60. Ibid. 
61. City/County Association of Governments of San Mateo County, "Measure M \$10 Vehicle Registration Fee Fiscal Year 2018-19 Annual Performance Report" (February 2020), accessed October 20, 2021, https://ccag.ca.gov/wp-content/ uploads/2020/03/Measure-M-Annual-Report-FY18-19 FINAL.pdf

62. "AB 194, Frazier. High-Occupancy Toll Lanes," in Streets and Highways Code (California), accessed October 20, 2021, https://leginfo.legislature.ca.gov/faces/ billNavClient.xhtml?bill id=201520160AB194.

63. Metropolitan Transportation Commission, "Historic Toll-Paid Vehicle Counts and Total Toll Revenues," accessed October 20, 2021, https://mtc.ca.gov/about-mtc/ what-mtc/mtc-organization/three-agencies-one/bay-area-toll-authority/historic-tollpaid.

64. Los Angeles County Metropolitan Transportation Authority, Adopted Budget FY19 (2019), 24, accessed October 20, 2021, http://media.metro.net/about us/finance/ images/fy19 adopted budget.pdf.

65. Golden Gate Bridge Highway and Transportation District, "Annual Vehicle Crossings and Toll Revenues" (2021), accessed October 20, 2021, https://www.goldengate.org/ bridge/history-research/statistics-data/annual-vehicle-crossings-toll-revenues/.

66. Santa Clara Valley Transportation Authority, "SR 237 Express Lanes Operational Report Fiscal Year 2019” (2019), 3, accessed October 20, 2021, https://www.vta. org/sites/default/files/2019-10/SR237\%20Express \%20Lanes\%20Operational\%20 Report\%20FY2019.pdf.

67. California Special Districts Association, “Impact Fees: Breaking New Ground Doesn't Need to Break the Bank" (August 27, 2018), accessed October 20, 2021, https:// www.csda.net/blogs/csda-admin/2018/08/27/impact-fees-breaking-new-grounddoesnt-need-to-bre.

68. California Legislative Information, "Fees for Development Projects" (January 1, 2021), accessed October 20, 2021, https://leginfo.legislature.ca.gov/faces/codes displaySection.$x h t m l$ ? sectionNum $=66000.5$. \&lawCode $=$ GOV.

69. Ibid.

70. Ibid.

71. Ibid.

72. City of Irvine, "Transportation Corridor Major Thoroughfare and Bridge Fee Program," accessed October 20, 2021, http://legacy.cityofirvine.org/civica/filebank/ blobdload.asp?BlobID=23621.

73. Western Riverside County Council of Governments, TUMF 2020 Annual Report 
(2020), accessed October 20, 2021, https://wrcog.us/DocumentCenter/View/8082/ Final-TUMF-2020-Annual-Report-PDF?bidld=.

74. City of San Ramon, "Refuse Vehicle Impact Fee" (2021), accessed October 20, 2021, https://www.sanramon.ca.gov/our city/departments and divisions/public works/garbage and recycling/refuse vehicle impact fee.

75. City of San Ramon, "City of San Ramon, California Comprehensive Annual Financial Report for the Fiscal Year Ended June 30, 2019" (December 18, 2019), 105, accessed October 20, 2021, https://www.sanramon.ca.gov/UserFiles/Servers/ Server 10826046/File/Our\%20City/Departments/Admin\%20Services/Finance/ Budget\%20Docs/cafr18-19.pdf.

76. Jon Sonstelie, "Parcel Taxes as a Local Revenue Source in California" (Public Policy Institute of California, April 2015), accessed October 20, 2021, https://www.ppic.org/ content/pubs/report/R 415JSR.pdf.

77. Legislative Analyst's Office, "Understanding Proposition 218" (1996), accessed October 20, 2021, https://lao.ca.gov/1996/120196_prop 218/understanding prop218 1296.html.

78. "Gilmore Vista County Service Area, California, Measure J, Parcel Tax (March 2020)," accessed October 20, 2021, https://ballotpedia.org/Gilmore Vista County Service Area.

79. "County Service Area 9 Zone 98122 Gilmore Vista Measure J," (March 3, 2020), accessed October 20, 2021, https://votersedge.org/ca/en/election/2020-03-03/eldorado-county/county-service-area-9-zone-98122-gilmore-vista/measure/measure-j.

80. California State Controller's Office, "Chapter 13000: Transient Occupancy Tax," in State of California County Tax Collectors' Reference Manual (2012), accessed October 20, 2021, https://sco.ca.gov/Files-ARD-Tax-Info/Tax-Collector-Ref-Man/ ctcrm chapter13.pdf.

81. "Chapter 1 Occupancy Taxes," in Revenue and Taxation Code $\S 7280$ (California), (2004).

82. Claudia Boyd-Barrett, "Despite Thomas Fire, Ojai Expects to Collect, Spend $\$ 500,000$ More Next Year," VC Star, June 26, 2019, accessed October 20, 2021, https://www.vcstar.com/story/news/local/2018/06/26/ojai-expects-collect-spend-500000-more-next-year/731140002/.

83. City of Ojai, "Measure 'C' - Hotel Tax (TOT) Increase," accessed October 20, 2021, https://ojaicity.org/measure-c-hotel-tax-tot-increase/.

84. The California Local Government Finance Almanac, "User Utility Tax Facts" (January 2017), accessed October 20, 2021, http://www.californiacityfinance.com/ 


\section{UUTfacts17.pdf.}

85. "Chapter 1.5 Local Agency Levy Powers and Limitations," Revenue and Taxation Code (California), § 7284.2.

86. California Legislative Analyst's Office, "Understanding Proposition 218" (December 1996), accessed October 20, 2021, https://lao.ca.gov/1996/120196 prop 218/ understanding prop218 1296.html.

87. "Isla Vista Community Services District, California, Measure R-2018, Utility User Tax (June 2018)," Ballotpedia, accessed October 20, 2021, https://ballotpedia.org/ Isla Vista Community Services District, California, Measure R-2018, Utility User Tax (June 2018).

88. Benjamin P. Fay and Carolyn Liu, "TNC-User Tax: Getting Rideshare Companies to Pay Their 'Fare' Share," League of California Cities City Attorneys' Annual Spring Conference, May 7, 2021, accessed October 20, 2021, https://www.cacities.org/ Resources-Documents/Member-Engagement/Professional-Departments/CityAttorneys/Library/2021/21-Spring/5-2021-Spring;-Fay-TNC-User-Tax-GettingRideshare.aspx.

89. Ibid.

90. Ibid.

91. "San Francisco, California, Proposition D, Ride-Share Business Tax to Fund Muni, Pedestrian, and Bicycle Services and Infrastructure (November 2019)," accessed October 20, 2021, Ballotpedia, https://ballotpedia.org/San Francisco, California, Proposition D, Ride-Share Business Tax to Fund Muni, Pedestrian, and Bicycle Services and Infrastructure (November 2019).

92. SPUR, "Prop D Ride-Hailing Tax," in SPUR Voter Guide; San Francisco November 2019 (November 2019), accessed October 20, 2021, https://www.spur.org/voterguide/san-francisco-2019-11/prop-d-ride-hailing-tax.

93. Fay and Liu, "TNC-User Tax."

94. Mountain View, California, Measure P, Per-Employee Business Tax (November 2018), accessed October 20, 2021, https://www.mountainview.gov/civicax/filebank/ blobdload.aspx?BlobID=27111; https://www.losaltosonline.com/news/sections/ business/183-business-features/57989-mv-council-advances-controversialbusiness-license-tax-hike; Mark Noack, "City Set to Launch New Headcount Tax," Mountain View Voice, December 17, 2019, accessed October 20, 2021, https://www. mv-voice.com/news/2019/12/17/city-set-to-launch-new-headcount-tax; and Katie Pyzyk, "Corporate 'Head Tax' Takes Effect in Google's Hometown," SmartCitiesDive, January 3, 2020, accessed October 20, 2021, https://www.smartcitiesdive.com/ news/corporate-head-tax-google-mountain-view-ca/569715/. 
95. City of Mountain View, "Business License Tax: Measure P Fact Sheet," accessed October 20, 2021, https://www.mountainview.gov/civicax/filebank/blobdload. aspx?BlobID=27147.

96. Southern California Association of Governments, "Enhanced Infrastructure Financing Districts (EIFD)" (2021), accessed October 20, 2021, https://scag.ca.gov/ post/enhanced-infrastructure-financing-district-eifd; Cynthia Amador, Enhanced Infrastructure Financing Districts (California Community Economic Development Association, February 2016), accessed October 20, 2021, https://cceda.com/wpcontent/uploads/EIFD-Resource-Guide-Feb-20161.pdf.

97. City of West Sacramento, "EIFD," accessed October 20, 2021, https://www. cityofwestsacramento.org/business/economic-development/enhanced-infrastructurefinancing-districts; Southern California Association of Governments, "City of West Sacramento Enhanced Infrastructure Financing District (EIFD)" (2021), accessed October 20, 2021, https://scag.ca.gov/funding-and-financing-tools-and-strategy/citywest-sacramento-enhanced-infrastructure-financing.

98. City of La Verne, "La Verne Enhanced Infrastructure Financing District (EIFD)" (2021), accessed October 20, 2021, https://www.cityoflaverne.org/index.php/home/ bulletins/287-socalgas-requests-regulatory-approval-to-replenish-natural-gassupply-at-aliso-canyon-storage-facility.

99. North Carolina Department of Transportation, FIRST Commission, "The North Carolina Highway Use Tax" (September 18, 2020), accessed October 20, 2021, https://www.ncdot.gov/about-us/how-we-operate/finance-budget/nc-first/ Documents/nc-first-brief-edition-3.pdf; North Carolina Future Investment Resources for Sustainable Transportation (FIRST) Commission, Final Commission Report (January 2021), accessed October 20, 2021, https://www.ncdot.gov/about-us/howwe-operate/finance-budget/nc-first/Documents/2021-01-08-final-report.pdf.

100. Illinois Policy, "Tax on Uber, Lyft Rides in Downtown Chicago Set to Triple" (December 19, 2019), accessed October 20, 2021, https://www.illinoispolicy.org/ tax-on-uber-lyft-rides-in-downtown-chicago-set-to-triple-jan-1/; ; Sara Freund, "Chicago's New Ride-Hailing Tax Begins Now, and It's the Country's Highest Fee," Curbed, January 6, 2020, accessed October 20, 2021, https://chicago.curbed. com/2019/12/2/20992472/chicago-transportation-tax-uber-lyft-taxi; and Fay and Liu (2021).

101. Zach Williams, "The Bill No One Wants to Enact During the Pandemic," City and State New York (December 9, 2020), accessed October 20, 2021, https://www. cityandstateny.com/articles/politics/new-york-city/bill-no-one-wants-pass-duringpandemic.html; "Bill No.: A06078" (New York) (2019), https://nyassembly.gov/ leg/?default_fld=\&leg_video=\&bn=A06078\&term=2019\&Summary=Y\&Text=Y.

102. North Carolina Future Investment Resources for Sustainable Transportation (FIRST) Commission, Final Commission Report (January 2021), 133-134, 
accessed October 20, 2021, https://www.ncdot.gov/about-us/how-we-operate/ finance-budget/nc-first/Documents/2021-01-08-final-report.pdf.

103. Ashley Langer, Vikram Maheshri, and Clifford Winston, "Ditching the Gas Tax: Switching to a Vehicle Miles Traveled Tax to Save the Highway Trust Fund" (The Brookings Institution, June 28, 2017), accessed October 20, 2021, https://www. brookings.edu/research/ditching-the-gas-tax-switching-to-a-vehicle-miles-traveledtax-to-save-the-highway-trust-fund/.

104. California Department of Transportation, "Road Charge Program," accessed October 20, 2021, https://dot.ca.gov/programs/road-charge.

105. Goldman, Corbett, and Wachs, "Local Option Transportation Taxes."

106. Andrea Hamre and David Kack, An Evaluation of the Montana Local Option Motor Fuel Excise Tax (Western Transportation Institute, June 2020), accessed October 20, 2021, https://westerntransportationinstitute.org/research projects/an-evaluationof-the-montana-local-option-motor-fuel-excise-tax/.

107. Amanda Bohman, "City of Fairbanks Adopts 5-Cent Tax on Gasoline," Fairbanks Daily News Miner, August 11, 2020, accessed October 20, 2021, http://www. newsminer.com/news/local news/city-of-fairbanks-adopts-5-cent-tax-on-gasoline/ article ec6cc6a6-dc3e-11ea-80ab-0f0fff100376.html.

108. Code of Virginia, § 58.1-2295.

109. Oregon Department of Transportation, "Motor Carrier Education Manual: WeightMile Tax," (February 2020), accessed October 20, 2021, https://www.oregon.gov/ odot/MCT/New\%20Carrier\%20Education\%20Manual/Section 3 Weight-MileTax. pdf.

110. New Mexico Department of Motor Vehicles, "Weight Distance," accessed October 20, 2021, http://www.mvd.newmexico.gov/weight-distance.aspx.

111. "SF 1602" (March 2, 2021), Minnesota Legislature, https://www.revisor.mn.gov/ bills/text.php?number=SF1602\&version=latest\&session=Is92\&session year $=2021 \&$ session number $=0$.

112. Carole Turley Voulgaris, "A TUF Sell: Transportation Utility Fees as User Fees for Local Streets and Roads," Public Works Management and Policy 21, no. 4 (2016): 305-323.

113. Audrey Moruza, A Guide to Transportation Funding Options Available to Virginia Jurisdictions (Virginia Transportation Research Council, February 2019), 69, accessed October 20, 2021, http://virginiadot.org/vtrc/main/online reports/pdf/19-r1. pdf. 
114. "HB 7175," Florida House of Representatives, accessed May 21, 2020, p. 39, https://www.flsenate.gov/Session/Bill/2014/7175/BillText/er/PDF.

115. This list of criteria is drawn from Asha Weinstein, et al, Transportation Financing Opportunities for the State of California (October 2006, Mineta Transportation Institute), accessed October 20, 2021, https://transweb.sjsu.edu/sites/default/files/ TransportFinanceOpps5 020107.pdf; and Financing Transportation in California: Strategies for Change (Institute of Transportation Studies, University of California at Berkeley, March 2001), accessed October 20, 2021, https://www.researchgate. net/publication/4803480 Financing Transportation in California Strategies for Change Final Draft. 


\section{BIBLIOGRAPHY}

Adams, Matthew, et al. Financing Transportation in California: Strategies for Change. Berkeley: Institute of Transportation Studies, University of California at Berkeley, 2001. Accessed October 20, 2021. https://www.researchgate.net/ publication/4803480 Financing Transportation in California Strategies for Change Final Draft.

Agrawal, Asha Weinstein, Hannah King, and Martin Wachs. The Impact of COVID-19 on California Transportation Revenue. San Jose: Mineta Transportation Institute, 2020. Accessed October 20, 2021. https://transweb.sjsu.edu/research/2018COVID-19-California-Transportation-Revenues.

Amador, Cynthia. Enhanced Infrastructure Financing Districts. Los Angeles: California Community Economic Development Association, 2016. Accessed October 20, 2021. https://cceda.com/wp-content/uploads/EIFD-Resource-Guide-Feb-20161. pdf.

American Public Transit Association. "APTA Ridership Trends." In Governor's Budget Summary 2021-22, 250-254 and 262-2, 2021. Accessed October 20, 2021. http://www.ebudget.ca.gov/2021-22/pdf/BudgetSummary/FullBudgetSummary.pdf.

Barton, Bruce. "MV Council Advances Controversial Business-License Tax Hike." Los Altos Town Crier, June 12, 2108. Accessed October 20, 2021. https://www. losaltosonline.com/news/sections/business/183-business-features/57989-mvcouncil-advances-controversial-business-license-tax-hike

Bohman, Amanda. "City of Fairbanks Adopts 5-cent Tax on Gasoline." Fairbanks Daily News Miner, August 11, 2020. Accessed October 20, 2021. http://www.newsminer. com/news/local news/city-of-fairbanks-adopts-5-cent-tax-on-gasoline/article ec6cc6a6-dc3e-11ea-80ab-0f0fff100376.html

Boyd-Barrett, Claudia. "Despite Thomas Fire, Ojai Expects to Collect, Spend $\$ 500,000$ More Next Year," VC Star, June 26, 2019. Accessed October 20, 2021. https:// www.vcstar.com/story/news/local/2018/06/26/ojai-expects-collect-spend-500-000more-next-year/731140002/.

California Air Resources Board. "California Climate Investments." In Annual Report to the Legislature on California Climate Investments Using Cap-and-Trade Auction Proceeds. 2019. Accessed October 20, 2021. https://ww2.arb.ca.gov/sites/default/ files/classic//cc/capandtrade/auctionproceeds/2019 cci annual report.pdf.

. "California Climate Investments Legislative Guidance." 2021. Accessed October 20, 2021. https://ww2.arb.ca.gov/resources/documents/california-climateinvestments-legislative-guidance.

California Department of Finance. Revenue Estimates. Accessed October 20, 2021. 
http://www.ebudget.ca.gov/2020-21/pdf/BudgetSummary/RevenueEstimates.pdf.

California Department of Motor Vehicles. "Appendix 1 A - County Fees." Accessed October 20, 2021. https://www.dmv.ca.gov/portal/dmv/detail/pubs/reg hdbk/ appendix/appendix1a countycityfees.

. "Appendix 1F - Fees." In Vehicle Industry Registration Procedures Manual. Accessed October 20, 2021. https://www.dmv.ca.gov/portal/handbook/vehicleindustry-registration-procedures-manual-2/appendix-1f-fees/.

. "DMV Collections 2018-2019." Accessed October 20, 2021. https://www.dmv. ca.gov/portal/wcm/connect/88c7fa82-7057-44d1-861e-d67a9dd0d90d/dmv collections.pdf.

California Department of Tax and Fee Administration. Annual Report of the California Department of Tax and Fee Administration. 2020. Accessed October 20, 2021. https://www.cdtfa.ca.gov/formspubs/pub306-2018-19.pdf.

. "Quarterly Distribution of District Tax, (from 2018 to Present)." January 6, 2021. https://www.cdtfa.ca.gov/formspubs/pub306-2018-19.pdf https://www.cdtfa.ca.gov/ dataportal/dataset.htm?url=LRBQtrDistDistrictTax.

. "Sales Tax Rates for Fuels." Accessed October 20, 2021. https://www.cdtfa. ca.gov/taxes-and-fees/sales-tax-rates-for-fuels.htm.

California Department of Transportation. Transportation Funding in California 2019. Accessed October 20, 2021. https://dot.ca.gov/programs/transportation-planning/ economics-data-management/transportation-economics/transportation-funding-inca.

California Department of Transportation, Division of Mass Transportation. "Transportation Development Act Statutes and California Codes of Regulations.” May 2003. Accessed October 20, 2021. http://actransit.org/wp-content/uploads/board memos/34ed2e.pdf.

California Legislative Analyst's Office. "California's Transportation System," by Mac Taylor. June 7, 2018. Accessed October 20, 2021. https://lao.ca.gov/Publications/ Report/3860.

. "Overview of the 2017 Transportation Funding Package," by Mac Taylor. June 8, 2018. Accessed October 20, 2021. https://lao.ca.gov/reports/2017/3688/2017transportation-package-060817.pdf.

. "The 2020-21 Budget: Transportation." February 10, 2020. Accessed October 20, 2021. Accessed October 20, 2021. https://lao.ca.gov/Publications/Report/4149.

. "The Budget Package: 2009-10 California Spending Plan." October 2009. 
Accessed October 20, 2021. https://lao.ca.gov/2009/spend plan/spending plan 09-10.aspx\#transportation.

. “Understanding Proposition 218." December 1996. Accessed October 20, 2021. https://lao.ca.gov/1996/120196_prop 218/understanding_prop218 1296.html.

California Local Government Finance Almanac. "User Utility Tax Facts." Updated January 2017. Accessed October 20, 2021. http://www.californiacityfinance.com/ UUTfacts17.pdf.

California Special Districts Association. "Impact Fees: Breaking New Ground Doesn't Need to Break the Bank." August 27, 2018. Accessed October 20, 2021. https:// www.csda.net/blogs/csda-admin/2018/08/27/impact-fees-breaking-new-grounddoesnt-need-to-bre.

. "Learn About Districts." 2020. Accessed October 20, 2021. https://www.csda.net/ special-districts/learn-about.

. "Special Districts: The Most Local of Local Governments." Accessed October 20, 2021. https://higherlogicdownload.s3.amazonaws.com/CSDA/b24702e8-8a424614-8c45-bc3cba37ea2c/Uploadedlmages/PDFs/2020 Special_Districts Guide WEB.pdf.

California State Auditor. "The Bradley-Burns Tax and Local Transportation Funds." November 30, 2017. Accessed October 20, 2021. https://www.auditor.ca.gov/pdfs/ reports/2017-106.pdf.

California State Controller's Office. "Chapter 13000: Transient Occupancy Tax." In State of California County Tax Collectors' Reference Manual, 2012. Accessed October 20, 2021. https://sco.ca.gov/Files-ARD-Tax-Info/Tax-Collector-Ref-Man/ctcrm chapter13.pdf.

. "Special Districts." Government Compensation in California. Accessed October 20, 2021. https://publicpay.ca.gov/Reports/SpecialDistricts/SpecialDistricts. aspx?year=2018.

City/County Association of Governments of San Mateo County. Measure $M$ - $\$ 10$ Vehicle Registration Fee Fiscal Year 2018-19 Annual Performance Report. February 2020. Accessed October 20, 2021. https://ccag.ca.gov/wp-content/uploads/2020/03/ Measure-M-Annual-Report-FY18-19 FINAL.pdf.

City of Irvine. Transportation Corridor Major Thoroughfare and Bridge Fee. April 10, 2020. Accessed October 20, 2021. Accessed October 20, 2021. http://legacy. cityofirvine.org/civica/filebank/blobdload.asp?BlobID=23621.

City of La Verne, "La Verne Enhanced Infrastructure Financing District (EIFD)," 2021. Accessed October 20, 2021. https://www.cityoflaverne.org/index.php/home/ 
bulletins/287-socalgas-requests-regulatory-approval-to-replenish-natural-gassupply-at-aliso-canyon-storage-facility.

City of Mountain View. "Business License Tax: Measure P Fact Sheet." Accessed October 20, 2021. https://www.mountainview.gov/civicax/filebank/blobdload. aspx?BloblD=27147.

City of Ojai. "Measure 'C' - Hotel Tax (TOT) Increase." Accessed October 20, 2021. https://ojaicity.org/measure-c-hotel-tax-tot-increase/.

City of San Ramon. "City of San Ramon, California Comprehensive Annual Financial Report for the Fiscal Year Ended June 30, 2019.” December 18, 2019.

Accessed October 20, 2021. https://www.sanramon.ca.gov/UserFiles/Servers/ Server 10826046/File/Our\%20City/Departments/Admin\%20Services/Finance/ Budget\%20Docs/cafr18-19.pdf.

. "Refuse Vehicle Impact Fee." Accessed October 20, 2021. https://www.sanramon. ca.gov/our city/departments and divisions/public works/garbage and recycling/ refuse vehicle impact fee.

City of West Sacramento. "EIFD." Accessed October 20, 2021. https://www. cityofwestsacramento.org/business/economic-development/enhancedinfrastructure-financing-districts.

Coleman, Michael. The California Municipal Revenue Source Handbook. $5^{\text {th }}$ ed. League of California Cities, 2019.

Congressional Research Service. "Funding and Financing Highways and Public Transit." May 11, 2020. Accessed October 20, 2021. https://fas.org/sgp/crs/misc/R45350. pdf.

Davis, Carl. Federal Inaction on the Gas Tax is Costing Us Dearly. Institute on Taxation and Economic Policy, February 26, 2020. Accessed October 20, 2021. https://itep. org/federal-inaction-on-the-gas-tax-is-costing-us-dearly/.

Davis, Jeff. "Highway Trust Fund 1010." Eno Center for Transportation, June 2, 2020. Accessed October 20, 2021. https://www.enotrans.org/article/highway-trust-fund101/\#what-constitutes-htf.

. "If Paid For By Motor Fuels Taxes, DeFazio Bill Would Double Federal Gas Tax." Eno Center for Transportation, June 4, 2020. Accessed October 20, 2021. https:// www.enotrans.org/article/if-paid-for-by-motor-fuels-taxes-defazio-bill-woulddouble-federal-gas-taxl.

. "Ten Years of Highway Trust Fund Bankruptcy: Why Did It Happen, and What Have We Learned." Eno Center for Transportation, September 5, 2018., https:// www.enotrans.org/article/ten-years-of-highway-trust-fund-bankruptcy-why-did-it- 
happen-and-what-have-we-learned/.

Eno Center for Transportation. "Highway Trust Fund (HTF) Reference Page." Accessed October 20, 2021.https://www.enotrans.org/htf/.

. "Table TF-6 Highway Trust Fund Results of Operations, Fiscal Year 2019." June 2020. Accessed October 20, 2021. https://www.enotrans.org/wp-content/ uploads/2020/06/HTF-Annual-Reports-1957-2019.pdf.

Fay, Benjamin P., and Carolyn Liu. "TNC-User Tax: Getting Rideshare Companies to Pay Their 'Fare' Share." League of California Cities City Attorneys' Annual Spring Conference, May 7, 2021. Accessed October 20, 2021. https://www.cacities.org/ Resources-Documents/Member-Engagement/Professional-Departments/CityAttorneys/Library/2021/21-Spring/5-2021-Spring;-Fay-TNC-User-Tax-GettingRideshare.aspx.

Federal Highway Administration. "Funding Federal-Aid Highways." August 15, 2018. Accessed October 20, 2021. https://www.fhwa.dot.gov/policy/olsp/ fundingfederalaid/07.cfm.

Freund, Sara. "Chicago's New Ride-Hailing Tax Begins Now, and It's the Country's Highest Fee." Curbed, January 6, 2020. Accessed October 20, 2021. https:// chicago.curbed.com/2019/12/2/20992472/chicago-transportation-tax-uber-lyfttaxi.

Garrett, Mark, Anne Brown, and Martin Wachs. "Funding Transportation in California: A History of Crises," California Journal of Politics and Policy 8, no. 4 (2016).

Golden Gate Bridge Highway and Transportation District. "Annual Vehicle Crossings and Toll Revenues." Accessed October 20, 2021. https://www.goldengate.org/bridge/ history-research/statistics-data/annual-vehicle-crossings-toll-revenues/.

Goldman, Todd, Sam Corbett, and Martin Wachs. Local Option Transportation Taxes in the United States (Part One). University of California Transportation Center, 2001.

Hamre, Andrea, and David Kack. An Evaluation of the Montana Local Option Motor Fuel Excise Tax. Western Transportation Institute, June 2020. Accessed October 20, 2021. https://westerntransportationinstitute.org/research projects/an-evaluationof-the-montana-local-option-motor-fuel-excise-taxl.

Illinois Policy. "Tax on Uber, Lyft Rides in Downtown Chicago Set to Triple." December 19, 2019. Accessed October 20, 2021. https://www.illinoispolicy.org/tax-on-uberlyft-rides-in-downtown-chicago-set-to-triple-jan-1/.

Institute for Local Government. Understanding the Basics of Municipal Revenues in California: Cities, Counties and Special Districts - 2016. 2016. Accessed October 20, 2021. https://www.ca-ilg.org/sites/main/files/file-attachments/basics of 
municipal revenue 2016.pdf.

Langer, Ashley, Vikram Maheshri, and Clifford Winston. "Ditching the Gas Tax: Switching to a Vehicle Miles Traveled Tax to Save the Highway Trust Fund." The Brookings Institution, June 28, 2017. Accessed October 20, 2021. https://www.brookings. edu/research/ditching-the-gas-tax-switching-to-a-vehicle-miles-traveled-tax-tosave-the-highway-trust-fund/.

Los Angeles County Metropolitan Transportation Authority. "Adopted Budget FY19." Accessed October 20, 2021. http://media.metro.net/about us/finance/images/ fy19 adopted budget.pdf.

. Metro Funding Sources Guide 2020. 2020. Accessed October 20, 2021. http:// media.metro.net/2020/Metro-Funding-Sources-Guide-2020.pdf.

McClelland, Robert. "The Ups and Downs of California's Gas Tax." Tax Policy Center, November 1, 2018. Accessed October 20, 2021. https://www.taxpolicycenter.org/ taxvox/ups-and-downs-californias-gas-tax.

Metropolitan Transportation Authority. "MTA 2019 Adopted Budget." February 2019. Accessed October 20, 2021. https://new.mta.info/sites/default/files/2019-03/MTA2019-Adopted-Budget-February-Financial-Plan 2019-2022.pdf.

Metropolitan Transportation Commission. "Historic Toll-Paid Vehicle Counts and Total Toll Revenues." Accessed October 20, 2021. https://mtc.ca.gov/about-mtc/what-mtc/ mtc-organization/three-agencies-one/bay-area-toll-authority/historic-toll-paid.

Moruza, Audrey. A Guide to Transportation Funding Options Available to Virginia Jurisdictions. Virginia Transportation Research Council, February 2019. Accessed October 20, 2021. http://virginiadot.org/vtrc/main/online reports/pdf/19-r1.pdf.

NCE. California Statewide Local Streets and Roads Needs Assessment: Final Report. League of California Cities, August 2021. Accessed October 20, 2021. https:// www.savecaliforniastreets.org/wp-content/uploads/2021/09/Statewide-2020-LocalStreets-and-Roads-Needs-Assessment-Final-Report-August-2021.pdf.

New Mexico Department of Motor Vehicles. "Weight Distance." Accessed October 20, 2021. http://www.mvd.newmexico.gov/weight-distance.aspx.

New York City Taxi and Limousine Commission. "New York State's Congestion Surcharge." Accessed October 20, 2021. https://www1.nyc.gov/site/tlc/about/ congestion-surcharge.page.

Newsom, Gavin. Governor's Budget Summary 2021-22. January 8, 2021. Accessed October 20, 2021. http://www.ebudget.ca.gov/2021-22/pdf/BudgetSummary/ FullBudgetSummary.pdf. 
North Carolina Department of Transportation, FIRST Commission. "The North Carolina Highway Use Tax." September 18, 2020. Accessed October 20, 2021. https:// www.ncdot.gov/about-us/how-we-operate/finance-budget/nc-first/Documents/ncfirst-brief-edition-3.pdf.

North Carolina Future Investment Resources for Sustainable Transportation (FIRST) Commission. "Final Commission Report." January 2021. Accessed October 20, 2021. https://www.ncdot.gov/about-us/how-we-operate/finance-budget/nc-first/ Documents/2021-01-08-final-report.pdf.

Novack, Mark. "City Set to Launch New Headcount Tax." Mountain View Voice, December 17, 2019. Accessed October 20, 2021. https://www.mv-voice.com/ news/2019/12/17/city-set-to-launch-new-headcount-tax

Oregon Department of Transportation. "Motor Carrier Education Manual: Weight-Mile Tax." February 2020. Accessed October 20, 2021. https://www.oregon.gov/odot/ MCT/New\%20Carrier\%20Education\%20Manual/Section_3 Weight-MileTax.pdf.

Peter G. Peterson Foundation. "The Highway Trust Fund Explained.” June 27, 2018. Accessed October 20, 2021. https://www.pgpf.org/budget-basics/budgetexplainer-highway-trust-fund.

Pyzyk, Katie. "Corporate 'Head Tax' Takes Effect in Google's Hometown." SmartCitiesDive, January 3, 2020. Accessed October 20, 2021. https://www. smartcitiesdive.com/news/corporate-head-tax-google-mountain-view-ca/569715/.

Santa Clara Valley Transportation Authority. "2016 Measure B." December 30, 2020. Accessed October 20, 2021. https://www.vta.org/projects/funding/2016measure-b.

. "SR 237 Express Lanes Operations Report Fiscal Year 2019." October 2019. Accessed October 20, 2021. https://www.vta.org/sites/default/files/2019-10/ SR237\%20Express\%20Lanes\%200perational\%20Report\%20FY2019.pdf.

Senate Governance and Finance Committee. Special District Fact Sheet. California Senate, September 2016. Accessed October 20, 2021. https://sgf.senate.ca.gov/ sites/sgf.senate.ca.gov/files/special district facts 2016.pdf.

Sonstelie, Jon. "Parcel Taxes as a Local Revenue Source in California." Public Policy Institute of California, April 2015. Accessed October 20, 2021. https://www.ppic. org/content/pubs/report/R_415JSR.pdf.

Southern California Association of Governments. "City of West Sacramento Enhanced Infrastructure Financing District (EIFD)." 2021. Accessed October 20, 2021. https://scag.ca.gov/funding-and-financing-tools-and-strategy/city-westsacramento-enhanced-infrastructure-financing. 
Southern California Association of Governments. "Enhanced Infrastructure Financing Districts (EIFD)." 2021. Accessed October 20, 2021. Accessed October 20, 2021. https://scag.ca.gov/post/enhanced-infrastructure-financing-district-eifd.

SPUR. "Prop D Ride-Hailing Tax. November 2019. Accessed October 20, 2021. https:// www.spur.org/voter-guide/san-francisco-2019-11/prop-d-ride-hailing-tax.

Voter's Edge California. "County Service Area 9 Zone 98122 Gilmore Vista Measure J." Accessed October 20, 2021. https://votersedge.org/ca/en/election/2020-03-03/ el-dorado-county/county-service-area-9-zone-98122-gilmore-vista/measure/ measure-j.

Voulgaris, Carole Turley. "A TUF Sell: Transportation Utility Fees as User Fees for Local Streets and Roads." Public Works Management and Policy 21, no. 4 (2016): 305323.

Weinstein, Asha, et al. Transportation Financing Opportunities for the State of California. San Jose: Mineta Transportation Institute. October 2006. Accessed October 20, 2021. https://transweb.sjsu.edu/sites/default/files/ TransportFinanceOpps5 020107.pdf.

Western Riverside County Council of Governments. TUMF 2020 Annual Report. 2020. Accessed October 20, 2021. https://wrcog.us/DocumentCenter/View/8082/FinalTUMF-2020-Annual-Report-PDF?bidld=.

Williams, Zach. "The Bill No One Wants to Enact During the Pandemic." City and State New York, December 9, 2020. Accessed October 20, 2021. https://www. cityandstateny.com/articles/politics/new-york-city/bill-no-one-wants-pass-duringpandemic.html. 


\section{ABOUT THE AUTHORS}

\section{ASHA WEINSTEIN AGRAWAL, PHD}

Dr. Agrawal is Director of the MTI National Transportation Finance Center and also Professor of Urban and Regional Planning at San José State University. Her research and teaching interests in transportation policy and planning include transportation finance, bicycle and pedestrian planning, travel survey methods, and transportation history.

\section{KEVIN YONG LEE}

Mr. Lee is an MTI Student Research Assistant and candidate for the degree of Master of Urban Planning at San José State University.

\section{SERENA E. ALEXANDER, PHD}

Dr. Alexander is Associate Professor of Urban and Regional Planning and Director of Urban Online at San José State University. Her research predominantly focuses on developing and implementing cutting-edge strategies to address climate change and climate justice. 


\section{MTI BOARD OF TRUSTEES}

Founder, Honorable

Norman Mineta*

Secretary (ret.),

US Department of Transportation

Chair,

Will Kempton

Retired Transportation Executive

Vice Chair,

Jeff Morales

Managing Principal

InfraStrategies, LLC

Executive Director, Karen Philbrick, PhD*

Mineta Transportation Institute

San José State University

Winsome Bowen

Chief Regional Transportation

Strategy

Facebook

David Castagnetti

Co-Founder

Mehlman Castagnetti

Rosen \& Thomas

Maria Cino

Vice President

America \& U.S. Government

Relations Hewlett-Packard Enterprise
Grace Crunican**
Owner
Crunican LLC

Donna DeMartino

Managing Director

Los Angeles-San Diego-San Luis

Obispo Rail Corridor Agency

John Flaherty

Senior Fellow

Silicon Valley American

Leadership Form

William Flynn *

President \& CEO

Amtrak

\section{Rose Guilbault}

Board Member

Peninsula Corridor

Joint Powers Board

Ian Jefferies*

President \& CEO

Association of American Railroads

Diane Woodend Jones

Principal \& Chair of Board

Lea + Elliott, Inc.
David S. Kim*

Secretary

California State Transportation

Agency (CALSTA)

Therese McMillan

Executive Director

Metropolitan Transportation

Commission (MTC)

\section{Abbas Mohaddes}

President \& $\mathrm{COO}$

Econolite Group Inc.

Stephen Morrissey

Vice President - Regulatory and

Policy

United Airlines

Dan Moshavi, PhD*

Dean, Lucas College and

Graduate School of Business

San José State University

Toks Omishakin*

Director

California Department of

Transportation (Caltrans)

Takayoshi Oshima

Chairman \& CEO

Allied Telesis, Inc.

\section{Greg Regan}

President

Transportation Trades Department, AFL-ClO

Paul Skoutelas*

President \& CEO

American Public Transportation

Association (APTA)

\section{Beverley Swaim-Staley}

CEO

Systra USA

\section{Beverley Swaim-Staley}

President

Union Station Redevelopment

Corporation

\section{Jim Tymon*}

Executive Director

American Association of

State Highway and Transportation Officials (AASHTO)

$*$ = Ex-Officio

$* *=$ Past Chair, Board of Trustees

\section{Directors}

\section{Karen Philbrick, PhD}

Executive Director

\section{Hilary Nixon, PhD}

Deputy Executive Director

\section{Asha Weinstein Agrawal, PhD}

\section{Education Director}

National Transportation Finance

Center Director

\section{Brian Michael Jenkins}

National Transportation Security

Center Director

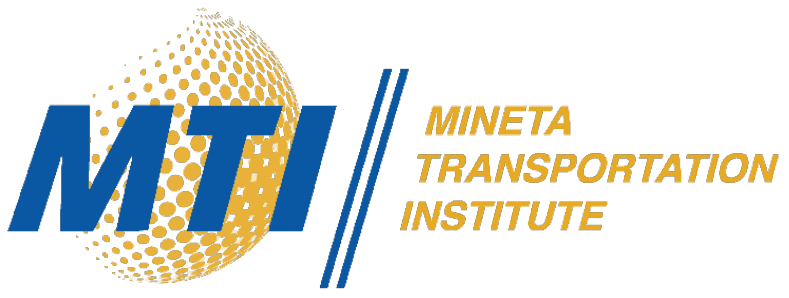

